\title{
Ethically Adrift: How Others Pull Our Moral Compass from True North, and How We Can Fix It
}

\section{Citation}

Loading... Moore, C., and F. Gino. "Ethically Adrift: How Others Pull Our Moral Compass from True North, and How we Can Fix It." Research in Organizational Behavior (forthcoming).

\section{Permanent link}

http://nrs.harvard.edu/urn-3:HUL.InstRepos:10996801

\section{Terms of Use}

This article was downloaded from Harvard University's DASH repository, and is made available under the terms and conditions applicable to Open Access Policy Articles, as set forth at http:// nrs.harvard.edu/urn-3:HUL.InstRepos:dash.current.terms-of-use\#OAP

\section{Share Your Story}

The Harvard community has made this article openly available.

Please share how this access benefits you. Submit a story.

\section{Accessibility}


Running Head: ETHICALLY ADRIFT

\title{
Ethically Adrift: How Others Pull Our
}

\section{Moral Compass from True North, and How We Can Fix It}

\author{
Celia Moore \\ London Business School
}

Francesca Gino

Harvard Business School

Forthcoming in Research in Organizational Behavior (2013).

FINAL DRAFT: June 17, 2013 


\begin{abstract}
This chapter focuses on the social nature of morality. Using the metaphor of the moral compass to describe individuals' inner sense of right and wrong, we offer a framework that identifies social reasons why our moral compasses can come under others' control, leading even good people to cross ethical boundaries. Departing from prior work on how individuals' cognitive limitations explain unethical behavior, we focus on socio-psychological processes that facilitate moral neglect, moral justification, and immoral action, all of which undermine moral behavior. In addition, we describe organizational factors that exacerbate the detrimental effects of each facilitator. We conclude by advising organizational scholars to take a more integrative approach to developing and evaluating theory about unethical behavior and by suggesting further study of interventions that might disempower these social triggers of unethical behavior, allowing us to regain control of our moral compasses.
\end{abstract}




\section{Contents}

1. The social nature of morality 1.1. The moral compass

1.2. Drift due to individuals' cognitive limitations

1.3. Drift due to others' control

2. Facilitators of moral neglect

2.1. Social processes that facilitate neglect

2.1.1. Social norms

2.1.2. Social categorization

2.2. Organizational aggravators of moral neglect

2.2.1. Socialization

2.2.2. Roles

2.2.3. Goals

2.3. Intrapersonal consequences of moral neglect

2.4 Summary

3. Facilitators of moral justification

3.1. Social processes that facilitate justification

3.1.1. Social comparison

3.1.2. Self-verification

3.2. Organizational aggravators of moral justification

3.2.1. Organizational identification

3.2.2. Group loyalty

3.2.3. Business framing and euphemistic language

3.2. Intrapersonal consequences of moral justification

3.3.1. Moral disengagement

3.3.2. Moral hypocrisy

3.3.3. Moral licensing

3.4 Summary

4. Facilitators of immoral action

4.1 Social processes that facilitate immoral action 


\subsubsection{Social conformity}

4.1.2. Diffusion of responsibility

4.1.3. Obedience to authority

4.2. Organizational aggravators of immoral action

4.2.1. Bureaucracy and anonymity

4.3.2. Hierarchy

4.3. Intrapersonal consequences of immoral action

4.4 Summary

5. An agenda for future research: Regaining control of our moral compass

5.1. Interpersonal processes

5.1.1. Promoting moral exemplars or referents

5.1.2. Monitoring as a reminder of one's best self

5.1.3. Careful and cognizant goal-setting

5.2. Intrapersonal processes

5.2.1. Increasing self-awareness

5.2.2. Increasing one's sensitivity to moral emotions

5.2.3. Expanding one's circle of moral regard

5.2.4. Practicing self-control

5.3 Moving forward

6. Conclusion

Acknowledgements

References 
A solitary organism has no need for moral rules, nor does a creature living among others without mutual dependency. - Henrik Høgh-Oleson, Human Morality and Sociality, (p. 3)

\section{The social nature of morality}

Humans are social animals, dependent on each other within communities for their physical and emotional well-being. Morality - the behavioral prescriptions and standards that define and direct us toward a virtuous life — is thus inescapably social as well. In many ways, morality emerged as a means of regulating our social relationships (Rai \& Fiske, 2011). As Høgh-Oleson put it, a solitary organism needs no moral rules, as he has no one but himself to harm, offend, or treat unfairly. The fact that human survival depends on finding ways to live together in peaceful, mutually supportive relations created an evolutionary imperative for fundamental moral behaviors such as altruism, trust, and reciprocity (Alexander, 2007; de Waal, 2006). In other words, we are moral because we are social.

However, much of our immorality can also be attributed to the fact that we are social animals. In this chapter, we use the metaphor of the moral compass to describe the common experience of an inner voice that motivates us toward ethically sound action, and we explore who and what controls the compass. ${ }^{1}$ Hint: it is often not the moral actor. Leaving aside the possibility that some people's moral compasses may be defective by design — a possibility supported by evidence that the brains of psychopaths, for example, function differently than those of others (de Oliveira-Souza et al., 2008)—we focus on how moral choices of the majority of us who believe fervently in our own ethicality (Van Lange, 1991; Van Lange \& Sedikides, 1998) are more

\footnotetext{
${ }^{1}$ In keeping with current usage (e.g., Tenbrunsel \& Smith-Crowe, 2008; Treviño, Weaver \& Reyolds, 2006), we use the terms "moral" and "ethical" synonymously, to refer to behavior that meets principles or standards of virtuous human behavior. In fact, the terms originated as synonyms. Cicero coined the Latin term "moralis" (proper behavior of a person in society) as a direct translation of the Greek "ethicus".
} 
swayed by social forces than we think we are. In other words, this chapter is about why we are immoral because we are social.

\subsection{The moral compass}

The inner voice that tells us what we should and should not do in various circumstances is often referred to as a moral compass (e.g., Bennett, 1995; Huntsman, 2010). The term is inspired by navigational compasses that use the earth's magnetic field to align a needle with the magnetic poles at the top and bottom of the Earth. A directional tool used for over 1,000 years (Aczel, 2001), a compass enables successful navigation because its needle consistently points North. Using the compass as a metaphor for our internal standards of behavior implies both that our moral center is stable (a compass always points North) and its orientation clear (the needle pointing North is plain to see). Indeed, people who feel remorseful about their unethical behavior often refer to having "lost" their moral compass. When he was sentenced to six years in prison for fraud and other offenses, former Enron CFO Andy Fastow claimed, "I lost my moral compass and I did many things I regret" (Pasha, 2006). Fastow's statement implies that if his moral compass had been in his possession, he would have made better choices.

In contrast, we argue that unethical behavior stems more often from a misdirected moral compass than a missing one. Given the importance of morality to our identities (Aquino \& Reed, 2002; Blasi, 1984), we would notice if our moral compass went missing. However, a present but misdirected moral compass could seduce us with the belief that we are behaving ethically when we are not, while allowing us to maintain a positive moral self-image. The idea that one's moral compass can veer away from "true North" has a parallel with navigational compasses.

Conditions within a local environment, such as the presence of large amounts of iron or steel, can cause the needle of a navigational compass to stray from magnetic North, a phenomenon called 
magnetic deviation. ${ }^{2}$ Explorers who are aware of this phenomenon can make adjustments that will protect them from going astray, but laymen can veer wildly off course without being aware they are doing so.

How can well-intentioned individuals veer off course ethically without recognizing they have done so? What forces are both powerful and subtle enough to cause people to believe their actions are morally sound when in fact they are ethically adrift? Existing research has offered two main explanations for this phenomenon. The first considers individuals who are ethically adrift to be "bad apples" whose moral compasses are internally damaged (cf., Felps, Mitchell, \& Byington, 2006; Kish-Gephart, Harrison, \& Treviño, 2010; Treviño \& Youngblood, 1990). This explanation for ethical drift harkens back to Aristotelian notions of human virtue and persists in contemporary discussions of character as the foundation of morality (cf., Doris, 2002).

Consistent with this explanation, scholars have identified some (relatively) stable individual differences that demagnetize moral compasses, leading to unethical behavior (DePalma, Madey, \& Bornschein, 1995; Kish-Gephart et al., 2010; Moore et al., 2012; Newstead, Franklyn-Stokes, \& Armstead, 1996; Perugini \& Leone, 2009). According to this view, a deviated moral compass is evidence of an individual's faulty human nature. Indeed, the idea that psychometric tests can identify "bad apples" before they are hired underlies the common practice of integrity testing among employers (Berry, Sackett, \& Wiemann, 2007; Van Iddekinge, Roth, Raymark, \& OdleDusseau, 2012).

In this chapter we focus instead on an increasingly dominant alternative view, grounded in moral psychology and behavioral ethics, that suggests that individuals' morality is malleable rather than stable (cf., Ayal \& Gino, 2011; Monin \& Jordan, 2009). This alternative perspective

\footnotetext{
${ }^{2}$ We thank Larry Lessig, director of the Edmond J. Safra Centre for Ethics at Harvard University, for introducing us to this phenomenon.
} 
proposes two main reasons why we can become ethically adrift: intrapersonal reasons (caused by human cognitive limitations) and interpersonal reasons (caused by the influence of others). We describe both of these reasons briefly below, before turning the rest of our attention to the latter of these two.

\subsection{Drift due to cognitive limitations}

A large body of empirical work documents individual biases and cognitive failings that affect our ethicality (Bazerman \& Tenbrunsel, 2011; Tenbrunsel, Diekmann, Wade-Benzoni, \& Bazerman, 2010; Tenbrunsel \& Messick, 2004). For example, (1) we tend to have an overly rosy view of both our past behavior and the likelihood that we will behave virtuously in the future (Tenbrunsel et al., 2010); (2) we are motivated to "forget" (Shu \& Gino, 2012) or fail to notice (Gino \& Bazerman, 2009) our own unethical actions; (3) we use our prior good deeds as a psychological license for less ethical action later on (Cain, Loewenstein, \& Moore, 2011; Effron, Cameron, \& Monin, 2009; Effron \& Monin, 2010; Merritt, Effron, \& Monin, 2010; Monin \& Miller, 2001); (4) we assess an action's ethicality based on how it is framed (Kern \& Chugh, 2009; Kramer \& Messick, 1996; Tenbrunsel \& Messick, 1999); (5) we use irrelevant information to evaluate unethical behavior (Baron \& Ritov, 2004; Cushman, Knobe, \& Sinnott-Armstrong, 2008; Gino, Shu, \& Bazerman, 2010; Spranca, Minsk, \& Baron, 1991); (6) we unconsciously prioritize self-serving over pro-social interests (Bersoff, 1999a; Tenbrunsel, 1998); and (7) we value non-moral goals more than moral ones (Barsky, 2008; Ordóñez, Schweitzer, Galinsky, \& Bazerman, 2009; Schweitzer, Ordóñez, \& Douma, 2004). These findings show how our ethicality is bounded, such that we cannot reliably know when our moral compass is deviating from true North (Chugh, Bazerman, \& Banaji, 2005; Kern \& Chugh, 2009; Murnighan, Cantelon, \& Elyashiv, 2001). 


\subsection{Drift due to others' control}

This chapter focuses on the second source of moral failings: interpersonal processes, those that originate in our social interactions. These interpersonal processes can provide "magnetic material" that causes our moral compasses to deviate from their true North. Though less studied than intrapersonal processes, interpersonal processes are central to understanding how people become ethically adrift. And a better understanding of how our social lives can lead us astray should help us wrest back control of our moral compasses.

The next three sections draw on classic research in social psychology to describe a number of ways that social influences, to which we are all susceptible, can cause our moral compasses to deviate, leading to negative ethical consequences. Each of these avenues of influence affects our moral compass in different ways, facilitating neglect of the moral import of our actions (Section 2), moral justification of immoral actions (Section 3), and immoral behavior (or the failure to behave ethically) (Section 4). Within each section, we describe (1) the social processes that facilitate the relevant moral compass deviation, (2) characteristics of organizational life that aggravate or amplify these effects, and (3) the intrapersonal consequences of succumbing to these moral compass deviations. We acknowledge that these delineations represent an oversimplification in the service of building theory and that these processes likely overlap in practice. Finally, Section 5 describes fruitful venues for future research by discussing how we can disempower these negative sources of social influence and regain control of our moral compasses. Figure 1 depicts our model of the social processes that can cause us to become ethically adrift. 


\section{Facilitators of moral neglect}

Moral development theory has highlighted the importance of awareness in the ethical decision-making process (Rest, 1986). When we not aware of the moral consequences of our actions, unethical behavior is both psychologically easier and more likely (Butterfield, Treviño, \& Weaver, 2000; Reynolds, 2006, 2008). While an absence of moral awareness is often discussed as an outcome of intrapersonal cognitive biases and limitations (Chugh et al., 2005; Tenbrunsel \& Messick, 2004), social processes can also facilitate neglect of the moral content of our decisions.

\subsection{Social processes that facilitate neglect}

The research overviewed in this section suggests that social norms and social categorization processes can lead us to neglect the true moral stakes of our decisions, dampening our moral awareness and increasing immoral behavior.

\subsubsection{Social norms}

Social norms are the general behavioral expectations that people hold in a given context, and represent one of the most powerful ways that people influence each other's behavior (Cialdini, Kallgren, \& Reno, 1991). Research on social norms suggests that the influence of others on individual behavior is driven in large part by observation and, subsequently, modeling of others. People are eager to behave in socially approved ways, and, as a result, attend both consciously and unconsciously to myriad environmental and social cues in search of guidance (Bettenhausen \& Murnighan, 1985; March, 1994; Weber, Kopelman, \& Messick, 2004). Rather than driving our own destiny, we look for external cues that allow us to relinquish control of the wheel. Put another way, "one means we use to determine what is correct is to find out what other people think is correct" (Cialdini, 1984, p. 116), a concept known as social proof. 
Researchers have demonstrated the power of social proof in multiple domains (Cialdini, 1984; Goldstein, Martin, \& Cialdini, 2008). We are more likely to engage in altruistic behavior if we see others doing so (Bryan \& Test, 1967) and more likely to ignore others' suffering if others near us are similarly indifferent (Latané \& Darley, 1970). We are even more likely to laugh at jokes if others are also laughing at them (Nosanchuk \& Lightstone, 1974; Smyth \& Fuller, 1972). In general, the more people engage in a behavior, the more compelling it becomes, but the actions of one person can still influence our behavior. Some of Bandura's classic studies (Bandura, 1973; Bandura, Ross, \& Ross, 1961; Bandura, Ross, \& Ross, 1963) showed how children exposed to an aggressive adult were considerably more aggressive toward a doll than were children who were not exposed to the aggressive model.

Together, this research suggests that others - either in groups or alone- help to establish a standard for ethical behavior through their actions or inaction. These "local" social norms provide individuals with the proof they need to categorize behavior as appropriate or inappropriate. Repeated exposure to behavioral norms that are inconsistent with those of society at large (as is the case, for example, with the subcultures of juvenile delinquents [Matza, 1964]) may socialize people to alter their understanding of what is ethical, causing broader moral norms to become irrelevant. Thus, when a local social norm neglects morally relevant consequences, it dampens moral awareness, and through this dampening, will increase unethical behavior.

\subsubsection{Social categorization}

Social categorization is the psychological process by which individuals differentiate between those who are like them (in-group members) and those who are unlike them (out-group members) (Hogg, 2007; Tajfel \& Turner, 1979). Social categorization happens universally and immediately in many contexts (Turner, 1999; Turner et al., 1987), on the basis of many 
similarities, such as age, marital status, ethnic background (Newcomb, 1961; Yun, 2002), assignment to the same group, such as the same work unit (Guzzo \& Dickson, 1996), or even on the basis of minimal and meaningless differentiators such as one's preference for one modern painter over another (Tajfel, 1970; Tajfel \& Turner, 1979). The groups we create through social categorization influence the types of relationships we form, and also how we evaluate the moral content of our actions (Rai \& Fiske, 2011).

Social categorization amplifies the effect of social norms, as norms have a stronger effect on our behavior when we perceive those enacting them to be similar to ourselves. In one classic study, pedestrians were more willing to return a "lost" wallet if it was accompanied by a letter written by someone they perceived to be similar to themselves (Hornstein, Fisch, \& Holmes, 1968). And in a large-scale survey of Australian citizens, individuals lowered their deduction claims on their tax returns when they received material about the social norm of tax compliance, but only when they identified with the group to which the norm was attributed (Wenzel, 2005). Even strangers who share the most irrelevant characteristics with us can trigger these identification processes, which in turn influence our behavior. In one study, hotel guests informed that other guests who had stayed in that same room had reused their towels led to towel usage rates $33 \%$ higher than guests who learned towel reuse rates for the hotel in general (Goldstein, Cialdini, \& Griskevicius, 2008).

Unfortunately, this means that if we socially identify with individuals who engage in unethical behavior, our own ethical behavior will likely degrade as well. In one study, college students were asked to solve simple math problems in the presence of others and had the opportunity to cheat by misreporting their performance and leave with undeserved money (Gino, Ayal, \& Ariely, 2009). Some participants were exposed to a confederate who cheated 
ostentatiously (by finishing the math problems impossibly quickly), leaving the room with the maximum reward. Unethical behavior in the room increased when the ostentatious cheater was clearly an in-group member (a member of the same university as the participants) and decreased when he was an out-group member (a student at a rival university) (Gino, Ayal, et al., 2009).

These findings suggest an intersection between social norm theory (Cialdini, Reno, \& Kallgren, 1990; Reno, Cialdini, \& Kallgren, 1993) and social identity theory (Tajfel, 1982). Essentially, people copy the behavior of in-group members and distance themselves from the behavior of out-group members, and then use this behavior to maintain or enhance their selfesteem, but in two different ways. In-group members' transgressions are perceived to be representative of descriptive norms (those that specify how most people behave in a given situation) and thus as less objectionable than the same behavior by an out-group member. In contrast, when assessing the immoral behavior of an out-group confederate, people highlight injunctive norms (those that refer to behaviors that most people approve or disapprove of) and distance themselves from this "bad apple." Highlighting the different types of norms, depending on whether an in-group or out-group member is modeling the behavior helps individuals maintain a distinctive and positive social identity for their in-group (Brewer, 1993; Tajfel, 1982). Another consequence of social categorization is out-group mistreatment. Categorizing individuals as members of an out-group allows us to dehumanize them (Bandura, Caprara, \& Zsolnai, 2000; Bandura, Underwood, \& Fromson, 1975; Bernard, Ottenberg, \& Redlich, 1971; Kelman, 1973), to exclude them from moral considerations (Opotow, 1990), or to place them outside our "circle of moral regard" (Reed \& Aquino, 2003), and thus mistreat them without feeling (as much) distress. At a fundamental level, we conceive of out-group members as less human and more object-like than in-group members (Haslam, 2006). Recent neurophysiological 
research has even found that individuals process images of extreme out-group members, such as the homeless or drug addicts, without many of the markers that appear when they look at images of other people (Harris \& Fiske, 2006). Brain-imaging data even show that individuals manifest fewer signs of cognitive or emotional distress when they are asked to think about sacrificing the lives of these extreme out-group members than when they contemplate sacrificing the lives of ingroup members (Cikara, Farnsworth, Harris, \& Fiske, 2010).

Given these findings, the self-sanctions typically triggered by the prospect of harming others will be subtler, if not absent, when we are contemplating harm against out-group rather than in-group members. Research shows that identifying others as members of out-groups facilitates soldiers' ability to take military action against them without the associated feelings of distress that typically accompany these behaviors (Fiske, Harris, \& Cuddy, 2004; Kelman \& Hamilton, 1989). Similarly, in their interpretation of the evidence provided by BBC Television's reenactment of Zimbardo's well-known prison experiment (Zimbardo, Haney, Banks, \& Jaffe, 1973), Haslam and Reicher (2006) propose that under conditions of high social identification with one's group, individuals feel free to act on impulses that they believe resonate with other ingroup members. Consequently, guards in the prison experiment who socially identified with other guards became more oppressive, and prisoners who socially identified with other prisoners were more likely to rise up against their oppressors. This observation highlights the important role of social identity in how people conceptualize available alternatives of action (which can include or exclude moral choices), as well as the critical role that the moral orientation of one's group plays in shaping our moral behavior.

Finally, social categorization also leads us to feel psychologically closer to those whom we have categorized as members of our in-group than to those we have categorized as out-group 
members (Jones, 2000). When people feel connected to others, they notice and experience others' emotions (Hatfield, Cacioppo, \& Rapson, 1994), including joy (Murray et al., 2002), embarrassment (Miller, 1987), and pain (Batson, 1991; Jackson, Brunet, Meltzoff, \& Decety, 2006). As individuals grow close, they take on properties of each other and psychologically afford each other "self" status (Galinsky \& Ku, 2004; Galinsky \& Moskowitz, 2000; Gunia, Sivanathan, \& Galinsky, 2009).

By blurring the boundaries between the self and others, psychological closeness can lead individuals to mimic close others' behavior, which can have detrimental ethical consequences. Using various manipulations for psychological closeness, Gino and Galinsky (2012) found that participants judged others' selfish or unethical actions as less morally problematic when they had a psychological connection to them. This led individuals who had formed a psychological connection with a wrongdoer to behave less ethically themselves. Indeed, copycat crimes are often perpetrated by individuals who feel a psychological connection to the models they are emulating (Surette, 2002, 2007; Tarde, 1968). In other words, having a psychological connection with an individual who engages in selfish or unethical behavior can influence how one's own moral compass is oriented.

\subsection{Organizational aggravators of moral neglect}

A number of aspects of organizational life exacerbate how these social processes facilitate moral neglect. Some commentators have described organizations as inherently amoral — that is, incapable of attending to the moral implications of their actions (Ashforth \& Anand, 2003; Brief, Buttram, \& Dukerich, 2001; Clinard \& Quinney, 1973, p. 212; Gross, 1978, 1980). Gross even claimed that "all organizations are inherently criminogenic" (Gross, 1978, p. 56). Others have asserted that organizations frequently develop cultures that tolerate violations of 
the law that benefit them (Apel \& Paternoster, 2009; Jackall, 1988; Sutherland, 1983).We now discuss how organizational socialization, roles, and goals can exacerbate the tendency for social processes to trigger neglect of the moral consequences of our actions.

\subsubsection{Socialization}

Organizational socialization sets up role expectations for individuals, communicates which organizational goals are important, and establishes appropriate ways to achieve them. Socialization processes per se are agnostic about questions of morality. However, when individuals are new to an organization, or when a pre-existing organizational culture resocializes individuals to new institutional demands, they look for cues from others to identify appropriate behavior (Bettenhausen \& Murnighan, 1985; Weber et al., 2004), and may acclimate to norms that are morally corrupting (Ashforth \& Anand, 2003; Brief et al., 2001; Coleman \& Ramos, 1998; Shweder, Mahapatra, \& Miller, 1990). Thus, through socialization processes, organizations can exacerbate social facilitators of moral neglect (Ashforth \& Anand, 2003).

Socialization to unethical practices can happen both consciously, when an individual resists objectionable practices until finally surrendering to them as inevitable, and unconsciously, when an individual becomes seduced by the positive material or psychological benefits of participating in corrupt behavior (Moore, 2009). Moral neglect is more closely related to seductive power of socialization. For example, Barbara Ley Toffler (2003) describes how the socialization practices at Arthur Andersen changed as the firm shifted from a relatively independent auditor that valued integrity to a highly competitive professional services firm where the importance of generating revenues began to overshadow the importance of providing accurate audits of clients' books. This industry-wide shift gradually eroded individual auditors' independence, changing socialization practices within firms like Andersen in ways that amplified 
the tendency among auditors to neglect the ethical consequences of some of their behaviors (Moore, Tetlock, Tanlu, \& Bazerman, 2006).

The human need to belong makes it easier to successfully socialize individuals into unethical behavior (Baumeister \& Leary, 1995). An example of this is described in journalist Michael Lewis' (1989) account of being socialized into the sales culture at investment bank Salomon Brothers. When he joined the firm, Lewis was informed that he could either fit in by becoming a "jammer," someone willing to unload whatever stocks would most benefit Salomon Brothers, regardless of their worth or benefit to the client, or to be labeled a "geek" or "fool"that is, someone who behaves more ethically (1989). Given these options, it becomes clear why many chose to become jammers.

Social networks play a role in normalizing unethical behavior and can be a source of moral compass deviations as well. Socialization to unethical practices may become "contagious" through the network of formal and informal relationships that organizations foster (Brass, Butterfield, \& Skaggs, 1998; Labianca, Brass, \& Gray, 1998). There have been limited efforts to study the social diffusion of unethical behavior within (MacLean, 2001; Mars, 1982) and across (Mohliver, 2012) organizations. However, the obvious importance of diffusion processes in social learning and the spread of corruption (Ashforth \& Anand, 2003; Brief et al., 2001; Kulik, O'Fallon, \& Salimath, 2008) heighten the importance of understanding how social networks facilitate ethical violations.

\subsubsection{Roles}

Roles - the sets of behavioral expectations that often surround one's position within an organization or profession - constrain and direct behavior in ways that also facilitate moral neglect. One way to understand how roles constrain behavior is through the organizational 
scripts they provide - the means by which people learn expected or appropriate behavior in their jobs (Gioia, 1992; Gioia \& Poole, 1984). Dennis Gioia was a recall coordinator at the Ford Motor Company in the 1970s when some of the first accident footage involving the Pinto car came across his desk. A spectacularly un-roadworthy car, the Pinto was susceptible to "lighting up" (bursting into flames) during low-speed, rear-impact collisions. Gioia explains how the scripts of his role, which included what to attend to and what to ignore when making recall decisions, prevented him from recognizing that leaving this model on the road could have fatal consequences. Specifically, his scripted cues for initiating a recall were restricted to whether negative outcomes occurred frequently and had directly traceable causes (1992). After determining that accidents involving "light ups" were relatively rare and did not have a clear cause, his investigations went no further, nor did he see this decision as morally problematic.

In extreme cases, such as the behavior of SS officers during the Holocaust (Arendt, 1963/1994) or prison guards in the Stanford prison experiments (Zimbardo, 2007; Zimbardo et al., 1973), roles direct individuals' behavior toward brutal ends. In the Stanford prison experiments, for example, one guard (randomly assigned to that role) wrote in his daily diary at the beginning of the experiment, "I cannot see a time when I might maltreat other living things." By day 5, this same guard had singled out a specific prisoner for "special abuse both because he begs for it and because I simply don’t like him" (Zimbardo et al., 1973). Zimbardo attributes the rapid deterioration of the guard's behavior to the zealousness with which the individual took on his role of prison guard. After the experiment, the participant who played the prison warden said, "While I believe that it was necessary for staff (me) to enact the warden role, at least some of the time, I am startled by the ease with which I could turn off my sensitivity and concern for others" 
(Zimbardo et al., 1973). Forty years later and in a different country, the BBC replicated a version of Zimbardo's experiment on air, with very similar results (Haslam \& Reicher, 2006).

\subsubsection{Goals}

Fundamental to organizational life, goals are often set for individual-, team-, and firmlevel activities, and are then regularly monitored and assessed in order to maximize performance. The evidence that goals motivate behavior is overwhelming (Locke \& Latham, 2002). However, concern that goals can degrade moral behavior is growing (Barsky, 2004, 2008; Ordóñez et al., 2009; Schweitzer et al., 2004). Individuals appear to be more likely to behave unethically when goals have been set for them, compared to when they have been asked simply to "do their best," particularly when they "just miss" those goals (Schweitzer et al., 2004). Goals often involve profit targets, driven by a "bottom-line mentality" (Wolfe, 1988) in which self-interest is the primary motivation and profit the primary objective. Contexts where profit is the primary goal may well exclude potentially more communal, altruistic, or pro-social motivations (Grant, 2007) or behaviors (Dozier \& Miceli, 1985; Van Dyne, Graham, \& Dienesch, 1994). An overview of corporate offenses also suggests that goal-oriented environments provide an "implicit message... that much more weight is attached to job completion than to legal or ethical means of accomplishment" (Yaeger, 1986: 110).

Goals promulgated by organizational authorities may cause employees to neglect the moral implications of the actions they take to meet these goals through a phenomenon called goal shielding. A series of studies have documented that people are better at meeting goals when other aspects of a situation, or potentially competing interests, have been "shielded" from immediate relevance (Shah, Friedman, \& Kruglanski, 2002). This shielding leaves more cognitive room to focus on and meet specific goals, but it also allows employees to omit 
additional factors - such as the ethical implications of the goal or the actions required to meet it - from their behavioral calculus. In a notorious example, the sales goals set in Sears, Roebuck \& Co.'s auto repair centers in the early 1990s prompted mechanics to regularly overcharge customers and undertake unnecessary work on vehicles (Yin, 1992). Goals also played a role in the dangerous design of the Ford Pinto. The company gave engineers a goal called the "Limits of 2,000 ," which required them to produce a car that was less than 2,000 pounds (to maximize fuel efficiency) and cost less than $\$ 2,000$ (to ensure a low price). This goal influenced the placement of the Pinto's rubber gas tank behind an insubstantial rear bumper, a major factor in the Pinto's tendency to "light up" in low-speed collisions (Gioia, 1992).

By mobilizing and focusing our behavior toward specific ends, goals lead us to neglect other (often desirable) behavior (Shah et al., 2002). This characteristic of goals is related to the role of incentives in reinforcement theory. Goals and incentives can both telescope our attention toward an outcome and blind us to the reasons the goals or incentives were set up in the first place. As an example, when police officers are given a target number of crimes to solve, they typically become motivated to pursue the crimes whose perpetrators are easiest to catch (such as prostitution) rather than the crimes whose perpetrators are more elusive but at least equally as important to catch (such as burglars) (Stone, 1988). And just as the "Limits of 2,000" goal undermined Ford's ability to meet their ultimate objective of designing and producing a fuelefficient car that would help them compete successfully with Japanese automakers, performance goals in schools have been blamed for causing widespread, systemic cheating on standardized tests, undermining the original objective of raising levels of student achievement (Bohte \& Meier, 2000; Jacob \& Levitt, 2003). Thus, goals and incentives can distort outcomes away from the type of behavior they are supposed to motivate, toward more nefarious ends (Grant, 2012). 


\subsection{Intrapersonal consequences of moral neglect}

When social processes facilitate us to neglect the consequences of our actions, the "moral colors [of those actions]...fade into bleached hues that are void of moral implications," (Tenbrunsel \& Messick, 2004, p. 224). Bird calls this phenomenon "moral blindness" (1996). Reynolds considers it "inattentiveness" to the moral content of decisions (2008). The intrapersonal consequences of moral neglect can also be considered more generally under the rubric of "bounded ethicality" (Chugh et al., 2005; Murnighan et al., 2001).

When we are aware of the moral aspects of a situation, we generally meet the normative expectations of behavior implied by it (Butterfield et al., 2000). In contrast, when we fail to recognize the moral consequences of a decision, it is easier for us to make unethical choices free from psychological distress, guilt, or regret. Consider a recent debate on the ethicality of tax avoidance. In June 2012, British Prime Minister David Cameron called out a popular British comedian, Jimmy Carr, for his participation in a scheme that was technically legal but that allowed him to pay income tax rates as low as $1 \%$ on his annual earnings of $£ 3.3$ million (Wintour \& Syal, 2012). Cameron accused participants in this scheme of "using the tax law to get a tax advantage that Parliament never intended" (HM Revenue and Customs, 2011, p. 7). Carr defended himself, tweeting, "I met with a financial advisor and he said to me: 'Do you want to pay less tax? It's totally legal.' I said: 'Yes.'” (Wintour \& Syal, 2012).

In Jimmy Carr's case, failing to consider that he might be crossing a moral boundary made it easier for him to respond "yes" to his financial advisor. Whether the scheme was a morally appropriate way to protect earnings was simply not part of Carr's decision criteria. The fact that other wealthy people (in-group members) participate in similar schemes made the activity normative and acceptable, fading its moral consequences. Cameron's public call-out of 
Carr forced him to integrate the potential ethical implications of tax avoidance into the next decisions he took regarding his tax arrangements. After this incident, Carr agreed to manage his finances more ethically (Wintour \& Syal, 2012). Though his change of heart may have been driven by concerns about his image, if the arrangements hadn't been morally suspect, they wouldn't have caused any public relations concerns. Thus, an awareness of the moral consequences of his tax planning choices played a role in his next steps even if his motive to change was not particularly virtuous.

\subsection{Summary}

Individuals are better equipped to make moral decisions if they are aware of the relevant moral values and implications of the decisions they are facing (Butterfield et al., 2000; Jones, 1991). We have discussed how social norms and social categorization can serve as facilitators of moral neglect and have identified two main ways in which this occurs. First, because we look to others for norms of appropriate behavior, we tend to emulate their behavior, regardless of its moral content. Second, social categorization creates in-groups with whom we identify and feel psychologically close, and we can be easily blinded to the unethical consequences of their behavior. Social categorization also facilitates unethical behavior toward out-groups, members of which are easy to mistreat. We also discussed three characteristics of organizational lifesocialization, roles, and goals - that exacerbate the social facilitators of moral neglect. Socialization amplifies moral neglect by habituating newcomers to norms absent of moral content. Organizational roles also amplify moral neglect, as they represent a compelling directive force on human behavior. Third, goals can direct and focus behavior and attention in a way that restricts moral concerns. Finally, we discussed the moral fading that occurs as a consequence of these processes. 


\section{Facilitators of moral justification}

If moral neglect represents the absence of conscious consideration of the moral domain, then moral justification refers to the process through which individuals distort their understanding of their actions. Moral justification allows us to reframe immoral actions as defensible, reducing the dissonance or anticipation of guilt that may function as an obstacle to unethical behavior, paving the way for it.

\subsection{Social processes that facilitate justification}

In this section, we discuss two ways that people support moral justifications of ethically suspect behavior so that they may engage in it without threatening one's positive self-image. First, we discuss how social comparison processes drive negative emotions like envy, which create justification for immoral actions. Second, we discuss how self-verification causes individuals to seek out information that confirms their views of themselves as moral, which may trigger moral hypocrisy or moral licensing. Both of these social processes provide individuals with the moral justification to engage in unethical behavior, and feel legitimate in doing so.

\subsubsection{Social comparison}

In his seminal analysis of social-comparison processes, Festinger (1954) proposed that individuals are motivated for adaptive reasons to assess their own abilities and opinions. Since we lack objective, nonsocial standards for most of these assessments, we tend to use otherstypically, similar others - as our points of comparison. People make both upward social comparisons, to targets who are (perceived as) better on some dimension, and downward social comparisons, to targets who are (perceived as) worse on some dimension. These different types of social comparisons serve different purposes in different circumstances, including selfevaluation and self-enhancement (Suls, Martin, \& Wheeler, 2002). 
The relevance of social-comparison processes to the moral domain is increasingly recognized (Monin, 2007). A number of studies in this domain suggest that the negative outcomes of unflattering social comparisons may be driven by the emotion of envy (Salovey \& Rodin, 1984; Tesser \& Collins, 1988). Envy, which arises frequently among workers and managers (Duffy \& Shaw, 2000; Vecchio, 2005), can be accompanied by feelings of inferiority and resentment (Monin, 2007), or a sense of injustice due to one's disadvantageous position, even when the disadvantage is purely subjective (Smith, Parrott, Ozer, \& Moniz, 1994). When social comparisons lead to envy, people are motivated to take actions to sabotage others or aggress against them (Vecchio, 2000), to undermine them socially (Duffy et al., 2012), or to engage in other harmful behaviors (Pruitt \& Kimmel, 1977; Smith \& Walker, 2000). The experience of envy can also motivate deception in interpersonal negotiations (Moran \& Schweitzer, 2008).

Employees can have strong reactions of envy toward customers with whom they compare unfavorably on visible signals of wealth (physical appearance, vehicles, and other possessions) (Gino \& Pierce, 2010). In related research, social comparisons were elicited by differences in resource allocation among individuals, Gino and Pierce (2009) found that participants in laboratory studies were willing to forgo payment in order to punish those they envied. Thus, social-comparison processes may cause individuals to sabotage or hurt others.

The envy elicited by disadvantageous social comparisons can lead to justification of unethical behavior by allowing individuals to believe that their actions will help them restore equity. Greenberg (1990) documented this motivation in a seminal study of employee theft in three manufacturing plants. After the loss of two major contracts, a manufacturing company temporarily cut factory workers' wages by $15 \%$ in two of three facilities. Employee theft 
increased in the two plants where wages had been cut but remained stable in the third plant. Greenberg attributes the theft increase to a reaction to perceived underpayment inequity (1990). Similar studies, in contexts ranging from fast-food restaurant workers (Hollinger, Slora, \& Terris, 1992) to nurses (Dabney, 1995), confirm that when employees perceive workplace practices to be unfair, they can easily reframe theft as an earned "benefit." Together, this research suggests that social comparisons and the emotions resulting from them often serve as a justification for immoral behavior, in part because of the negative emotions they elicit. This is especially true when we compare unfavorably to others and when we find these unfavorable comparisons to be unfair.

\subsubsection{Self-verification}

A second facilitator of moral justification is self-verification. According to selfverification theory (Swann, 1983, 1990), people are motivated to verify, validate, and sustain their existing view of themselves. Research has identified two main ways that the need to selfverify within our social environment affects our behavior (for a thorough review, see Leary, 2007). First, it motivates us to interact with people who see us as we see ourselves (Swann, Pelham, \& Krull, 1989), since they can confirm our self-concept. This tendency can lead individuals to create and maintain cultures that may perpetuate morally questionable behaviors, as individuals will seek to remain in the company of those who confirm their positive self-regard, regardless of their actions. Enron CEO Jeff Skilling, for example, reportedly surrounded himself with "yes men" who built up his ego without questioning his decisions (Zellner, 2002). These "yes men" may have helped Skilling confirm his positive self-views as a competent executive without drawing attention to his morally questionable behaviors. 
Second, people also solicit self-verifying feedback from others (Robinson \& Smith-Lovin, 1992; Sedikides \& Strube, 1997) and look for, see, and remember information that is consistent with their existing self-concepts (Baumeister, Bratslavsky, Finkenauer, \& Vohs, 2001; Swann \& Read, 1981). As a result, people often misinterpret feedback in ways that are consistent with their self-concepts and dismiss information that is accurate but inconsistent with those self-concepts (Doherty, Weigold, \& Schlenker, 1990). Though self-verification has not been studied in the context of ethical behavior, we suggest that the human need to self-verify will facilitate moral justification. Since individuals' self-concepts consistently involve strong beliefs in their own morality (Baumhart, 1968; Brenner \& Molander, 1977; Tyson, 1990, 1992), they are likely to seek out and attend to evidence that supports this aspect of their self-concept. Individuals will also likely dismiss negative feedback about their own morality, making it more difficult for them to correct their unethical behavior.

The need to self-verify will thus interact with the human tendency to see oneself as moral and result in construing one's actions as moral, regardless of their actual ethical content. This may help to explain why individuals who have engaged in morally questionable behavior often persist in the sincere belief that they behaved ethically. This list includes Franklin Raines, former CEO of mortgage company Fannie Mae, who maintained he did "nothing wrong" even after incurring \$100 million in penalties for accounting fraud (Labaton, 2004), former Lehman Brothers CEO Richard Fuld, who claimed he and his colleagues were "unfairly vilified" by accusations of accounting fraud (Zibel \& Aversa), and Conrad Black, former CEO of the Canadian firm Hollinger, who claimed he would never "have dreamt" of breaking laws, even after serving three years in prison for fraud (Whyte, 2011). 
Strong beliefs in one's own ethicality can be exacerbated by the false consensus bias, or the assumption that others hold the same views that we do (Ross, Greene, \& House, 1977). Flynn and Wiltermuth (2010) recently posited two reasons why the false consensus bias will likely increase unethical behavior in organizations. First, people tend to avoid moral dialogue in organizations (Sabini \& Silver, 1982), denying them access to others' true opinions on morally relevant matters. Second, the networked structure of most organizations means that individuals who are highly central, such as CEOs, will be particularly likely to believe that other members share their views. Indeed, in samples of MBA students and executives, the authors confirm that individuals who are central in their social networks are more likely than others to think that others agree with their views on ethical matters (Flynn \& Wiltermuth, 2010). This may lead central actors in social networks to feel justified behaving in certain ways simply because they mistakenly assume that others think like they do.

\subsection{Organizational aggravators of moral justification}

In this section, we discuss three ways in which organizational life can exacerbate our tendencies towards moral justification. Both identification with one's organization and loyalty to one's work group will support moral justification by providing legitimating reasons to do wrong. We also discuss framing and euphemistic language as an aggravator of moral justification because of how commonly organizations rename practices or products to make them seem more innocuous and hence more legitimate than they actually are.

\subsubsection{Organizational identification}

If moral justification involves sanctifying corrupt practices by appealing to worthy ends (White, Bandura, \& Bero, 2009), then the organization represents a powerful "higher cause" to which individuals can appeal to make suspect practices appear morally worthy. Unethical 
behavior in support of organizational ends has been termed unethical prosocial behavior because it is undertaken for ostensibly good reasons - to benefit the company (Umphress \& Bingham, 2011). Empirical research supports the idea that identification with other organizational members will exacerbate unethical behaviors undertaken to support corporate goals, as long as employees believe their efforts will be reciprocated (Umphress, Bingham, \& Mitchell, 2010). Likewise, lack of social identification with coworkers will exacerbate unethical behavior toward the organization and its members. For example, in both student teams and organizational samples, Duffy and her colleagues found that individuals with low levels of social identification with team members were more likely to socially undermine them than those who identified with their colleagues more strongly (Duffy et al., 2012). As an aside, failing to socially identify with group members may also provide the absence of social conformity pressures needed for whistleblowing (a possibility we discuss in Section 5).

Fortunately, there is also evidence that identification with more virtuous institutions can mitigate unethical behavior. A study of academic misconduct found that students who strongly identified with their school reported lower levels of academic misconduct than did those with weaker attachments to their institution (Finn \& Frone, 2004). Similarly, a study of 200 employees and their supervisors in China found that the relationship between ethical leadership and performance could be partially explained by the degree to which ethical leaders elevated positive models of organizational identification among their subordinates (Walumbwa et al., 2011). Organizational identification, then, can work both ways: exacerbating unethical outcomes when institutions are corrupt and mitigating unethical outcomes when they are more virtuous. Clearly, in both instances, the organization represents a powerful force that can be marshaled to justify specific practices, whether virtuous or vicious. 


\subsubsection{Group loyalty}

Just as organizations can be a compelling source of moral justification, so too can groups of organizational members. As Ashforth and Anand (2003) note, group loyalty is a fundamental facilitator of moral justification. People may abandon global or universal moral norms in order to give preference to those close to them (Rorty, 2001). While there are likely evolutionary roots for this preference (Haidt \& Bjorklund, 2008; Haidt \& Graham, 2007), loyalty toward those close to us inherently undermines moral norms of fairness (Berlin \& Williams, 1994). This is perhaps most evident in cases of nepotism, when close others are given undue preference in employment or resource allocation (Becker, 1957).

Sometimes the role of group loyalty in moral justification is explicit. Just as loyalty to one's nation or religious faith is invoked to justify war (Kramer, 1990; Rapoport \& Alexander, 1982), loyalty to other organizational members is invoked to justify questionable business practices. For example, anthropological studies of police corruption have described how officers often prioritize allegiance to colleagues above any responsibility to report internal misconduct to superiors (Heck, 1992). A study of the self-regulation of misconduct within the U.S. Military Academy also supports the idea that explicit notions of loyalty toward one's fellow officers provide a justification to normalize and refrain from reporting officially prohibited behavior (Pershing, 2002). In this study, midshipmen who (in the view of their peers) over-reported military code violations were called "honor Nazis," a disparaging term for those whose loyalty to the institution overrode loyalty to their more local group. As Pershing points out, in many organizational contexts where cohesive groups develop, loyalty to one's subgroup will override loyalty to the organization (2002). 
Using loyalty to one's group to morally justify unethical behavior also happens unconsciously in organizations. Groupthink, a phenomenon originally described in a study of disastrous U.S. foreign policy decisions, refers to a mode of thinking that develops in cohesive in-groups "when the members' strivings for unanimity override their motivation to realistically appraise alternative courses of action" (Janis, 1972, p. 8-9). Groupthink is relevant to unethical outcomes (Sims, 1992). Though empirical evidence is lacking, anecdotal evidence abounds on groups reaching immoral consensus decisions that allow members to maintain a positive selfimage. For example, in his analysis of the Nixon administration, Raven writes that the "us vs. them" mentality promoted by the president led to lapses in moral restraint (1974).

Groupthink leads to these types of suboptimal decisions because the drive for individuals to agree-which serves the positive social purposes of minimizing internal conflict and reaffirming group membership ("us")_ overrides any desire to raise issues in the search for a better decision. Though the exact processes and outcomes of groupthink remain contested, some have proposed that it represents a collective attempt to maintain a positive image of one's group (Turner \& Pratkanis, 1998). This theory is consistent with the notion that self-verification processes can facilitate moral justification, particularly when group members seek feedback from others to verify their positive group identity in the domain of morality (Leach, Ellemers, \& Barreto, 2007).

\subsubsection{Business framing and euphemistic language}

Similar to the exacerbating effect of goals, business language specifies what counts as important, valuable, rewarded, and expected in organizations. Language creates and substantiates our reality and constrains the options we see and from which we choose (Ferraro, Pfeffer, \& 
Sutton, 2005). It also frames how we view those options and provides substance for the justifications of our choices.

Empirical studies confirm that euphemistic labels can psychologically sanitize unethical practices, facilitating our participation in them. In part, this is because language signals how a decision ought to be understood, which in turn changes the appropriate choice in that particular context. For example, framing a social dilemma decision in economic terms ("invest in a joint investment fund") results in less cooperation than framing it in cooperative terms ("contribute to a social event”) (Pillutla \& Chen, 1999). Likewise, framing a prisoner's dilemma in economic terms ("Wall Street game") results in higher rates of defection than framing it in communal terms ("community game") (Liberman, Samuels, \& Ross, 2004). Factors other than language can also affect how a decision is framed, and then made. After Tenbrunsel and Messick found that individuals more often chose to engage in undesirable (but potentially profitable) behavior in the presence of sanctions against it (1999), follow-up studies confirmed that when sanctions from external regulators were a possibility, participants framed undesirable behavior as a "business" decision rather than as a "personal" or "ethical" one.

Sanitizing terms are used for a wide range of harmful or otherwise prohibited business practices. For example, the firm USEcology, whose name suggests environmental friendliness, has specialized in radioactive and hazardous waste disposal since 1952. Many forms of fraud have colorful names that evoke images far removed from their actual, more nefarious content: "channel stuffing" refers to the practice of booking sales to distributors as final sales to customers, "candy deals" involve temporarily selling products to distributors and promising to buy them back later with a kickback added on, "tango sheets" are false books used to calculate earnings inflation and hide expenses in order to hit quarterly targets (Lohr, 2004), and "cookie 
jar reserves" refer to using surpluses from profitable years to improve the balance sheet during leaner years (The Economist, 2010). These terms support moral justification by obfuscating the true purpose of unethical activities and making consideration of their true nature less likely.

Sometimes, individuals must practice using euphemistic language in order to psychologically commit to it. Jackall writes about executives rehearsing "legitimations"official ways of blandly discussing morally questionable corporate decisions and gradually becoming comfortable repeating these excuses publicly (1988, p. 188-190). Kreps and Monin (2011) elaborate on how individuals within organizations manage mismatches between the private desire or motivation to frame an issue morally with the public or organizational need to diminish the issue's moral content. One outcome of this tension is "moral muteness" (Bird, 1996), or finding non-moral or pragmatic language to capture the value that the individual privately moralizes, such as calling layoffs "right-sizing". However, using non-moral language facilitates disengagement from the moral content of the action, reducing the uncomfortable feelings triggered by the mismatch and making it easier for people to engage in the morally questionable behavior.

\subsection{Intrapersonal consequences of moral justification}

If the main intrapersonal consequence of moral neglect is a failure to acknowledge or integrate moral considerations into decision making and behavior, moral justification prompts us to reconstrue immoral choices as morally innocuous or even morally righteous. Intrapersonally, moral justification can manifest as moral disengagement, moral hypocrisy, and moral licensing - consequences that pervert how we evaluate moral decisions, allowing us to make immoral choices more easily. 


\subsubsection{Moral disengagement}

Moral disengagement refers to a set of eight cognitive mechanisms that deactivate the self-sanctions that typically compel us to behave morally (Bandura, 1990, 1999). Employing these mechanisms reduces the cognitive dissonance individuals experience when engaging in morally questionable behavior and enables their participation in them without the typically attendant negative cognitive or emotional consequences. Thus, during his trial for war crimes, Adolf Eichmann consistently maintained that he would only "have had a bad conscience if he had not done what he had been ordered to do - to ship millions of men, women and children to their death" (Arendt, 1963/1994, p. 25). Eichmann, who here has employed the moral disengagement mechanism of displacing one's moral agency to organizational superiors, can legitimately claim he was not guilty because his evaluation of his own actions has been so thoroughly distorted.

People can morally disengage either actively or unconsciously. For example, when conditions permit disadvantageous social comparisons, individuals may actively employ justifications for immoral behavior. If one construes employee theft as simply a means of restoring equity (Greenberg, 1990) or as a response to employers defaulting on their own obligations (Kemper, 1966), then stealing seems almost the moral thing to do. Once habituated to morally disengaged cognitions such as "I deserve this from my employer," individuals may slide into a wide range of undesirable behaviors, including dishonesty, theft, and cheating (Detert, Treviño, \& Sweitzer, 2008; Moore et al., 2012); social undermining (Duffy et al., 2005); and sexual harassment (Claybourn, 2011) in the belief that these actions are justified. Moral disengagement thus operates as a moral compass disruptor, moving the needle towards an activity that can be morally justified through its mechanisms. 


\subsubsection{Moral hypocrisy}

A second intrapersonal consequence of moral justification is moral hypocrisy, or "morality extolled... not with an eye to producing a good and right outcome but in order to appear moral yet still benefit oneself' (Batson et al., 1997, p. 1335). When people have moral justifications at hand, they can more easily engage in immoral actions without detrimentally affecting their self-image as a moral person. In a creative series of studies, Batson and his colleagues demonstrated that people were more likely to treat themselves preferentially (and others unfairly) as long as the context offered an easy justification or way to obscure the fact that they were doing so (Batson et al., 1997; Batson et al., 1999).

Some evidence suggests that the willingness to cut oneself moral slack in the face of temptations toward self-interest is volitional rather than automatic (Valdesolo \& DeSteno, 2008). On a fundamental level, we realize we are being unfair, but the presence of a justification for our behavior allows us to appear to meet moral considerations rather than actually meeting them. Over time, though, individuals can become skilled at neutralizing morally questionable activities (Bersoff, 1999b; Valdesolo \& DeSteno, 2008), and behavior that may have started with a need to volitionally rationalize it becomes a less considered or even a mindless or automatic choice.

\subsubsection{Moral licensing}

A third intrapersonal consequence of the social availability of moral justifications is moral licensing. In the last decade, researchers have studied "compensatory ethics", the phenomenon of using prior moral actions as a credential or license to commit later unethical actions and prior unethical actions as a motivation to engage in later ethical ones (for reviews, see Merritt et al., 2010; Miller \& Effron, 2010; Monin \& Jordan, 2009; Zhong, Ku, Lount, \& Murnighan, 2010). Moral justification that occurs through self-verification may offer individual 
license to engage in unethical acts in the following way. A common self-verification tactic is for individuals to seek positive feedback about themselves as moral individuals. Armed with positive information about themselves, people may then feel licensed to engage in unethical acts, or have the "perception that they are permitted to take an action or express a thought without fear of discrediting themselves" (Miller \& Effron, 2010, p. 116). For example, individuals who wrote about themselves using explicitly positive (caring, generous, fair) moral words, later engaged in less altruistic behavior than did those who wrote about themselves using negative (greedy, mean, selfish) words (Sachdeva, Iliev, \& Medin, 2009).

Our social groups also provide ammunition for moral licensing. In a series of studies, Kouchaki (2011) finds that moral behavior exhibited by an individual's in-groups can function as a vicarious license for that individual's own discrimination, particularly when his or her social identification with the in-group is high. Together, these results lead to the disheartening conclusion that when we are motivated or tempted to behave immorally, we will seek and use any available information to justify that behavior to ourselves.

\subsection{Summary}

Even when individuals are aware of the ethical dimensions of the choices they are making, they may still engage in unethical behavior as long as they recruit justifications for it. In this section, we discussed the role of two social-psychological processes-social comparison and self-verification - that facilitate moral justification, which will lead to immoral behavior. We also discussed three characteristics of organizational life that amplify these social-psychological processes. Specifically, we discussed how organizational identification, group loyalty, and framing or euphemistic language can all affect the likelihood and extent to which individuals justify their actions, by judging them as ethical when in fact they are morally contentious. Finally, 
we discussed moral disengagement, moral hypocrisy, and moral licensing as intrapersonal consequences of these social facilitators of moral justification.

\section{Facilitators of moral inaction or immoral action}

Individuals may be aware of the moral content of their actions, make accurate judgments about what is right and wrong, and still be unable to follow through with desirable action. In this section, we overview how social processes create obstacles to doing the right thing or motivation to do the wrong thing.

\subsection{Social processes that facilitate moral inaction or immoral action}

A number of social influences can create obstacles between good intentions and ethical behavior. In this section, we explore social conformity, obedience to authority, and diffusion of responsibility as three types of social influence that make moral action less likely.

\subsubsection{Social conformity}

Asch's foundational experiments in the 1950s demonstrated how individuals tend to conform to the social agreement they perceive rather than to their own intuition about what is correct (Asch, 1951, 1955). In his most classic experimental paradigm, participants in a room filled with confederates were asked to assess which of a series of lines is the same length as a "standard line." Though the correct answer was always unambiguous, in 12 of 18 trials, the confederates first unanimously agree to a wrong answer. In the face of this social consensus, $75 \%$ of respondents provided a patently wrong answer at least some of the time (Asch, 1955). When the conforming individuals were asked why they provided wrong answers, they responded that they feared looking foolish and, in the face of social consensus, began to doubt their own intuitions. Asch's study suggests that when situations instigate an internal conflict between the 
fear of potential social embarrassment and the fear of potential inaccuracy, the fear of social consequences looms larger (cf., Warren \& Smith-Crowe, 2008).

It is easy to see how social conformity, in the right context, may make it difficult for people to follow through on a decision to behave morally, even when their moral awareness is activated and moral judgments are accurate. A partial explanation for the low rates of whistleblowing in corporate wrongdoing must be the compulsion to behave in concert with majority views; accordingly, best estimates are that less than half of those who witness organizational wrongdoing report it (Near \& Miceli, 1996; Rothschlid \& Miethe, 1999). Social conformity also helps us understand why individuals mimic the egregious behavior of others, such as American soldiers' torture of prisoners at Abu Ghraib in Iraq (Hersh, 2004).

\subsubsection{Diffusion of responsibility}

The general finding that the presence of others inhibits the impulse to help individuals in distress, known as the bystander effect, is driven in large part by social conformity (Latané \& Darley, 1970: 38). People are less likely to respond to an emergency when others are present, particulary when those present are passive. In a classic study, participants began completing surveys in a room that slowly filled with smoke (Latané \& Darley, 1968). Participants who believed they were alone left the room to report the smoke $75 \%$ of the time. But when participants were in the room with two passive confederates, only $10 \%$ got up to report the smoke. We seem to prefer inaction to the risk of acting first, which opens up the possibility of being judged as socially inappropriate, leaving one exposed to the potential ridicule of others.

Even the perception that others are witnessing the same emergency decreases one's likelihood of acting. In another classic study (Darley \& Latané, 1968), individuals heard a confederate having what seemed to be a severe epileptic fit in another room. Eighty-five percent 
of participants who believed they were the only other person within earshot reported the seizure in under one minute. In contrast, only $31 \%$ of those who were led to believe there were four others within earshot reported the emergency before the end of the six-minute experiment, and those who did took more than twice as long to respond as those who believed they were alone.

The explanation of this moral inaction is often desribed in terms of diffusion of responsibility: when the cost of inaction can be shared among multiple parties, individuals are less likely to take responsibility for action themselves. The bystander effect is robust in part because it allows people to take advantage of a bias that causes us to evaluate acts more harshly than omissions and direct causation as worse than indirect causation (Baron \& Ritov, 2004; Greene \& Darley, 1998). Legal and normative differences between acts and omissions (failing to act) continue to be debated in philosophy and legal scholarship (e.g, Moore, 1993) in part because, psychologically, we evaluate their consequences as qualitatively different.

\subsubsection{Obedience to authority}

Moral inaction may also be facilitated by individuals' tendencies to obey legitimate authority figures. As Milgram's famous obedience experiments showed 50 years ago, individuals relinquish personal agency for their own actions easily in the face of requests from an authority figure $(1963,1974)$. In the standard paradigm for these experiments, participants assigned to the role of "teacher" were instructed to administer electrical shocks of increasing degrees of severity to confederate "learners" who offered incorrect answers to questions. Two-thirds of participants continued to increase the severity of the electrical shocks to the maximum extent, as long as the authority figure verbally required them to do so (Milgram, 1974).

Obedience to authority appears to be a deep-seated psychological response that only a minority of individuals naturally resist (Milgram, 1974). Though Milgram did show that 
obedience levels could be reduced when additional confederates in the experiment refused to shock the "learner" in a dramatic way, a recent partial replication the experiments suggested that subtler examples (or models) of refusal behavior do little to reduce compliance rates (Burger, 2009). More recent studies have reached similar results in employment contexts, finding that individuals obey the requests of supervisors to discriminate against potential employees, independent of their own beliefs about race (Brief et al., 1995; Brief et al., 2000).

\subsection{Organizational aggravators of immoral (in)action}

Organizations can exacerbate social influences that lead to moral inaction or immoral action because they are commonly structured in ways that allow us to minimize moral agency for our actions. First, bureaucracy and the anonymity it provides exacerbate the diffusion of responsibility - the minimization of moral agency that occurs when one is a member of a group. Second, hierarchy exacerbates obedience to authority and the displacement of moral agency onto organizational superiors.

\subsubsection{Bureaucracy and anonymity}

Being a member of a bureaucratic organization can create a personal sense of anonymity, a state that facilitates negative moral outcomes both structurally and psychologically. Within a bureaucratic structure, an individual is "protected, in so far as the office sets the limits of his responsibility, from both the bludgeons of critics and the sharp thrust of his own conscience" (Hughes, 1937, p. 406). Moreover, the legal protections afforded to corporations limit individual employees' criminal and civil liability for actions undertaken on the job (Bakan, 2004). As the Lord Chancellor of England stated 300 years ago, the corporation "has no soul to be damned, and no body to be kicked" (cited in Coffee, 1981), a fact that facilitates corporate misconduct and creates a conundrum for its prosecutors. The effects of anonymity are amplified in large 
bureaucracies, as both size and division of labor make responsibility more challenging to assess and penalties for misconduct more challenging to inflict.

Psychologically, anonymity facilitates immoral action by allowing people to feel shielded from personal responsibility. When they are anonymous, individuals feel less "like themselves", and as if their actions are unobserved and thus will have no consequences. The process of becoming anonymous, known as de-individuation, has been elicited experimentally using a number of methods. Two interesting studies found that the de-individuating effect of Halloween costumes increased morally questionable behavior (Diener, Fraser, \& Beaman, 1976). In one of the studies, children engaged in doubly aggressive play (compared to their baseline level) after putting on costumes, though they had been told that aggression would reduce their odds of earning tokens they could cash in for prizes. In a second study, actual trick-or-treaters were given the opportunity to steal candy and money, with the anonymity of their costumes either protected or undermined (depending on whether they were asked their name and where they lived). The experimenters considered the anonymity afforded by being a trick-or-treater in a group rather than alone as a second experimental factor. They found an effect both for the anonymity provided by wearing costumes and for trick-or-treating as part of a group: trick-or-treaters assured of anonymity in groups stole the most (57\% of them); $21 \%$ stole if they were alone but assured of anonymity, or if they were in groups but asked to reveal their identities; and only $7 \%$ of those without either the protection of group membership or costumed anonymity committed theft (Diener et al., 1976).

In organizations, uniforms can be used to create anonymity or encourage role-relevant behavior. Zimbardo used uniforms as "costumes" of anonymity in his prison experiments; guards wore sunglasses to shield their gaze from prisoners (Zimbardo, 2007). In a different experiment 
ostensibly about creativity and stress, individuals were given the opportunity to give electric shocks to other participants. Half the participants were de-individuated by wearing baggy lab coats, nametags with only numbers on them, and hoods or masks to cover their faces; the other half wore "individuating" nametags and no costumes. Psychologically shielded from the consequences of their actions through their costumes, de-individuated (more anonymous) participants delivered twice the level of shock to "victims", compared to individuated participants (Zimbardo, 1970).

Relating back to the prior section, organizations also create a sense of anonymity through language. For example, when the executive branch of the U.S. government orders activities with negative consequences, press releases often report that the "White House" was responsible for the decision, thus replacing a human agent (someone inside the White House) with an inanimate object, making responsibility more difficult to determine and assign. Interestingly, the organizational conditions that facilitate anonymity, such as those that keep decisions from being associated with any individual actor, also aggravate moral neglect. As Diane Vaughan writes about the organizational conditions that led to the space shuttle Challenger disaster:

$[\mathrm{R}]$ outine characteristics of inter- and intra-organizational relationshipsconditions common to all organizations...concealed the seriousness of the technical problem on the Solid Rocket Boosters from people outside the work group, preventing them from identifying the trend and intervening in some way that might have altered the decision-making pattern prior to the Challenger launch decision. (1998, p. 42).

Thus, bureaucracy not only makes its members and their actions anonymous to outsiders, but also to each other.

\subsubsection{Hierarchy}

Bureaucracies create hierarchy, or the ordering of individuals in positions of greater and lesser power and social status (Magee \& Galinsky, 2008; Weber, 1994). Hierarchy provides 
individuals a route through which they can absolve themselves of personal responsibility for acts undertaken either for themselves directly, or for their team or organization. In their analysis of the My Lai massacre in Vietman, Kelman and Hamilton cite hierarchy as a cause of this "crime of obedience": the massacre was initiated by an order that became perverted as it filtered through a chain of subordinates (1989). Similar to anonymity, individuals are both legally protected from bearing full responsibility for their actions when ordered to do so by military superiors (Kelman \& Hamilton, 1989, p. 6) and psychologically protected from the weight of moral responsibility when they can effectively transfer responsibility to a superior.

Bandura calls the psychological passing of moral responsibility up through the chain of command "displacement of responsibility" (Bandura, 1990, 1999). Milgram refers to it as the "agentic shift", a transition from an autonomous state where one feels a personal sense of responsibility for one's actions to feeling like one is simply an agent acting on someone else's behalf (1974). When debriefed, many participants in the obedience experiments commented, "If it were up to me, I would not have administered shocks to the learner" (Milgram, 1974). Of course, their behavior was up to them, but the presence of a legitimate authority figure allowed them to pass off their moral responsibility to another. Similarly, when former U.S. National Security Advisor and Secretary of State Condoleezza Rice was asked about her involvement in authorizing practices during the Iraq War that could be considered torture, she said, "I didn't authorize anything. I conveyed the authorization of the administration to the agency" (quoted in Dowd, 2009). Interestingly, her words capture both displacement of her moral responsibility to her superiors, and the reduction of moral responsibility provided by anonymity.

The temptation to conform to the unethical requests of legitimate superiors can be seductive, given the control that supervisors have over their subordinates' organizational futures. 
Organizations create obligations of fealty to supervisors; in exchange for pledges of loyalty, supervisors offer some protection from the consequences of subordinates' mistakes and the potential of advancing through the organization on their coattails (Jackall, 1988, pp. 17-24). Though the benefits of this fealty can be substantial, so can its costs. Scott Sullivan rose through the ranks of WorldCom quickly in part because of his willingness to do whatever CEO Bernie Ebbers asked, including misrepresenting the organization's financial statements (Jeter, 2003). Ultimately, Sullivan was sentenced to five years in prison for his role in WorldCom's fraud, but true to the legal protections hierarchical structures afford subordinates, the sentence paled next to Ebbers' 25-years (Searcey, Young, \& Scannell, 2005).

\subsection{Intrapersonal consequences of immoral action}

A common assumption is that the intrapersonal consequences of unethical actions are negative emotions such as guilt or shame (Eisenberg, 2000; Klass, 1978). However, empirical evidence that individuals actually do feel guilty after engaging in unethical actions is weak. The few studies that have assessed negative emotions after unethical acts use contexts where the moral responsibility for the action was unambiguous and there was direct harm clearly caused to an identifiable other (Brock \& Buss, 1964; Buss \& Brock, 1963; Okel \& Mosher, 1968; Ring, Wallston, \& Corey, 1970). Recent evidence suggests that unethical behavior may elicit negative emotions such as guilt less often than expected (Ruedy, Moore, Gino, \& Schweitzer, 2013), particularly when the harm resulting from it is unclear and personal responsibility for it ambiguous. In these cases, denial and self-deception may be more common outcomes of unethical behavior, as they better protect the self-concept from negative attributions.

A growing body of work explores self-deception as a natural outcome of unethical behavior. Due to our deep-seated need to see ourselves as moral (Leach et al., 2007), we go to 
great lengths to avoid viewing our actions as immoral. When one can delegate one's moral agency to someone else or somewhere else, it becomes possible to commit unethical acts or to avoid engaging in moral ones without commensurate feelings of personal responsibility. In fact, McGraw (1987) found that people experience higher levels of guilt following an accidental transgression than an intentional one, suggesting that we are able to avoid negative feelings even after acts where more direct culpability pertains.

There are other ways in which unethical actions lead to self-deception. Shu and her colleagues have studied how individuals conveniently "forget" relevant moral rules after engaging in unethical actions, even though they were no less likely to forget other more morally neutral information (Shu \& Gino, 2012; Shu, Gino, \& Bazerman, 2011). In addition, Chance and her colleagues found that individuals who were given an opportunity to see the answers while completing a test performed better than those who could not, suggesting they viewed correct answers before responding (Chance, Norton, Gino, \& Ariely, 2011). However, they attributed their performance to higher levels of competence rather than to having seen the correct answers, clear evidence of self-deception. Similarly, rates of unethical behavior increase when participants are afforded "wiggle room" in the way they interpret cheating or dishonesty, in part by facilitating self-deception about the nature of the act (Dana, Weber, \& Kuang, 2007; Mazar, Amir, \& Ariely, 2008; Shalvi, Dana, Handgraaf, \& De Dreu, 2011).

Together, these results suggest that the intrapersonal consequence of immoral actions is self-deception that allows one to maintain a positive self-image, rather than negative emotions such as guilt or shame, particularly when the ethicality of those actions is open to interpretation.

\subsection{Summary}


The findings we discussed in this section identify three mechanisms that create obstacles to moral action. First, social conformity encourages us to follow the lead of others, regardless of where they take us. Second, when the psychological costs of non-intervention are shared, individuals feel less responsible for their actions. Third, individuals find it challenging to resist the requests of those with power over them. Together, these mechanisms explain why failing to behave ethically can be psychologically and socially easier than making more virtuous choices, even if people recognize the ethical implications of their decisions and understand the immorality of the actions they are considering. We also discussed two main features of organizations that exacerbate the social facilitators of moral inaction, namely bureaucracy and hierarchy. By affecting people's perceptions of their moral agency, these two features can increase the likelihood of unethical behavior, even when the moral content of the decision is clear and there is little justification for following through with a morally problematic decision. Finally, though negative emotions (such as guilt) are a possible outcome of immoral action, research suggests that more common intrapersonal outcomes may be the delegation of one's moral agency to others, denial and self-deception.

\section{An agenda for future research: Regaining control of our moral compass}

Margolis (2009) argues that social science has been better at identifying causes of unethical behavior than at identifying and testing potential correctives for it. He challenges us to look beyond the antecedents of unethical behavior and focus on how to achieve more optimal moral outcomes. We agree with this suggested focus on possible interventions, and now offer several important directions for future research that focus on positive interventions rather than descriptions of the status quo. In this section, we draw from the body of research reviewed in this chapter to suggest how we can build better moral infrastructures, both within ourselves and 
within our organizations (Tenbrunsel, Smith-Crowe, \& Umphress, 2003). In so doing, we outline what we believe to be an important agenda for future research, one that focuses on positive interventions rather than descriptions of the status quo.

\subsection{Interpersonal processes}

\subsubsection{Promoting moral exemplars or referents}

As discussed earlier, social categorization processes have a number of effects on our moral awareness: we consider behavior manifest by members of our in-groups as morally acceptable, even when it may not be (Gino, Ayal, et al., 2009; Gino, Gu, \& Zhong, 2009), and we define unethical behavior as less problematic as long as it is committed against a member of an out-group (Bandura et al., 1975; Bernard et al., 1971; Kelman, 1973). However, witnessing unethical behavior committed by an out-group member makes us less likely to follow suit (Gino, Gu, et al., 2009); similarly, witnessing positive behavior by an in-group member may inspire us to imitate it (Oliner \& Oliner, 1988). These findings suggest that choosing the right exemplars of moral behavior-either positive in-group members to emulate or negative out-group members from which to differentiate oneself — may strengthen the magnet inside one's moral compass. Indeed, in their study of rescuers of Jews during the Holocaust, Oliner and Oliner found that, compared to non-rescuers, rescuers had more models in their close social circles who demonstrated similar altruistic behaviors, such as participation in the Resistance (1988).

Our role models need not be aspirational (such as Ghandi or Mother Theresa) to be effective. In keeping with the idea that social groups can be elicited subtly (Tajfel \& Turner, 1979), simple role model primes, such as thinking of one's parents, have been shown to help people improve their moral judgment and regulate their moral behavior. Eibach, Libby, and Ehrlinger (2009) found that, after a parental role is primed, parents express more moral 
disapproval of offensive acts than do people without children. In a similar vein, Fitzsimons and Bargh (2003) found that priming different types of relationship partners (e.g., a friend or mother rather than a coworker) could produce positive, goal-directed behavior such as helping. For some, positive role model priming may involve religious symbols. For example, priming the idea of God increases prosocial behavior (Shariff \& Norenzayan, 2007).

Together, these results suggest that surrounding ourselves with people or symbols we would like to emulate — or even thinking about them in their absence — should strengthen the magnets inside our moral compasses. However, as the work on moral licensing suggests, this must be done with care. If priming role models causes one to recall one's own moral actions, it may function as a license for later bad behavior. If priming role models instead encourages aspirational behavior, then this tactic can likely be used to promote positive outcomes.

From an organizational perspective, the ways in which firms can foster moral exemplars in leadership roles may be a fruitful area for further investigation (Mayer, Aquino, Greenbaum, \& Kuenzi, 2012). Brown, Treviño, and Harrison (2005) define ethical leadership as "the demonstration of normatively appropriate conduct through personal actions and interpersonal relationships, and the promotion of such conduct to followers through two-way communication, reinforcement, and decision-making” (p. 120). Thus, leaders can be encouraged to use transactional efforts (e.g., communicating, rewarding, punishing, emphasizing ethical standards) as well as modeling to influence their followers to behave ethically (Mayer et al., 2012; Mayer et al., 2009; Walumbwa et al., 2011).

Communication in particular will be central in the work of ethical leaders. As research on positive workplace behavior suggests, people behave better toward each other and the organization when high levels of procedural justice exist (fair procedures, clearly communicated) 
and when leaders are oriented toward acting in their followers' best interests (Ehrhart, 2004). Sensitive interpersonal treatment appears to help people cope better in situations that may elicit concerns about fairness, mitigating the negative repercussions that often stem from them (Tyler \& Bies, 1990). As Greenberg's study (1990) demonstrated, employees reacted more positively to a temporary pay cut, and stole less from the organization in retaliation for it, when management clearly and comprehensively explained the reasons for it.

Though this research provides reason for optimism that moral exemplars may provide fuel for individuals to behave in more virtuous ways, we know very little about how individuals choose or use moral exemplars. Fortunately, the simple presence of another person making positive moral choices improves people's behavior. In the studies that examined the effect of an observer on children's aggression, adding a second adult who commented negatively about the situation (e.g., saying “That's wrong," or “That's awful”) dampened levels of aggression (Hicks, 1968; Siegel \& Kohn, 1959). And, as we know from the Asch and Milgram studies, the presence of one other who is willing to make a brave, and therefore risky, choice paves the way for others to follow.

Research has also not considered how individuals become those "first" non-conformists. However, one's status in the group may be relevant. The fact that Warrant Officer Hugh Thompson did not belong to $1^{\text {st }}$ Platoon, C Company (the brigade that led the My Lai massacre) may have facilitated his resistance to it; his active efforts triggered the belated cease-fire (Kelman \& Hamilton, 1989). As an outsider, Thompson was less subject to the social conformity pressures that likely kept other platoon members from stopping the massacre when they had the chance. In this way, being an outsider may facilitate whistle-blowing, a decision akin to being a "first" non-conformist. 
It would be both theoretically rich and practically relevant to study the precursors of individuals becoming moral exemplars themselves, something that Zimbardo is now considering with his "Hero Project” (Zimbardo, 2007; see also http://www.lucifereffect.com/heroismsignup.htm). Future research should thus examine the factors that determine how individuals choose moral exemplars, how organizations can promote the visibility of moral exemplars and encourage social identification with these virtuous individuals, and how this identification translates into positive action.

\subsubsection{Monitoring as a reminder of one's best self}

Individuals' sense of anonymity—which, as we have discussed, facilitates unethical behavior - is undermined when they believe they are being monitored. Studies have shown that even when people are told their actions are anonymous, they respond to subtle cues of being watched, such as the presence of eye-like spots on the background of the computer they are using (Haley \& Fessler, 2005). Similarly, Bateson, Nettle, and Roberts (2006) put the image of a pair of eyes over an "honesty box" for contributions in a shared coffee room to elicit the sense of being monitored. The presence of this image was sufficient to increase ethical behavior (i.e., contributions to the honesty box). More formal surveillance strategies have also decreased rates of unethical behavior (Covey, Saladin, \& Killen, 1989). These results suggest that being monitored by others may increase our moral awareness (or, at least, our self-consciousness) and, as a result, reduce the influence of wrongdoers to whom we feel connected.

Monitoring is certainly a key lever available to organizations and governments as they try to influence individuals toward exemplary behavior, but future research is needed to disentangle when and under what conditions monitoring systems lead to more ethical behavior and when they backfire. Tenbrunsel and Messick's work (1999) shows that external monitoring changes 
the way that people frame choices, moving them from an ethical frame, in which they make choices because of a sense of intrinsic value, to a business frame, in which they make choices to maximize profit. This suggests that extrinsic controls can undermine the intrinsic motivation to behave morally (Deci \& Ryan, 1985), something that research in economics confirms can be an unintended consequence of regulation (Frey, 1992; Frey \& Stutzer, 2006). It seems that monitoring may work when it subtly reminds people to be their own best selves but is less effective when it provides an external, amoral reason to comply with an external request (such as a regulation or policy).

\subsubsection{Careful and cognizant goal-setting}

As we have seen, goals are a primary means of motivating and directing behavior in organizations, but they can backfire when it comes to ethical behavior (Magee, Kilduff, \& Heath, 2011; Ordóñez et al., 2009). Setting overly narrow or ambitious goals can blind individuals to other important objectives (Kerr, 1975; Staw \& Boettger, 1990), and over-commitment to goals can motivate individuals to do whatever it takes to reach them. However, carefully designed goals may have the power to appropriately direct behavior toward ends that meet both business and moral obligations. Ordóñez and her colleagues offer a series of questions to ask when designing goals aimed at meeting both economic and moral objectives, including whether goals are too specific or too challenging, whether they include an appropriate time frame, and how they will affect risk taking, intrinsic motivation, and organizational culture (Ordóñez et al., 2009).

Though the potential dangers of goals are now widely acknowledged, we still know little about how to set goals that encourage high performance while ensuring people keep ethical priorities in mind. Clearly, organizations are not going to abandon goals any time soon. However, remaining aware of how all goals restrict attention (Shah et al., 2002), coupled with a better 
understanding of how to set the right goals the right way, would go a long way toward improving societal outcomes.

\subsection{Intrapersonal processes}

People can also try to influence their own intrapersonal processes in their attempts to regain control of their moral compass. Such efforts might involve attempts to heighten one's dynamic sense of moral self-regard. Increasing one's self awareness and encouraging sensitivity to moral emotions (dampening opportunities for moral neglect), expanding one's circle of moral regard (reducing opportunities for moral justification), and practicing self-control (reducing the extent to which one delegates one's moral agency) are all fruitful avenues to explore.

\subsubsection{Increasing self-awareness}

Individuals differ in the extent to which they are aware of their own attitudes, feelings, needs, desires, and concerns, a trait called private self-consciousness (Fenigstein, Scheier, \& Buss, 1975). In general, people who are dispositionally high in private self-consciousness tend to be more aware of their cognitive processes and more cognizant of the factors that affect their decisions and actions. Private self-consciousness promotes introspection and, as a result, is associated with correspondence between attitudes and behavior (Pryor et al., 1977). It is also associated with a tendency to resist persuasion (Froming, Walker, \& Lopyan, 1982; Hutton \& Baumeister, 1992) and efforts to change one's attitudes (Scheier \& Carver, 1980). Similarly, trait mindfulness, a practice that encourages an awareness of both oneself and one's cognitive biases, has been associated with improvements in ethical behavior (Ruedy \& Schweitzer, 2010).

Individuals can heighten their self-consciousness or self-awareness in simple ways that may improve ethical outcomes. For instance, when a mirror was placed directly in front of participants as a manipulation of self-awareness, levels of unethical behavior decreased from $71 \%$ 
to $7 \%$ (Diener \& Wallbom, 1976). In another study that also used direct reflection in a mirror to temporarily increase self-consciousness, participants became less susceptible to persuasion by weak arguments (Hutton \& Baumeister, 1992). Batson and colleagues also found that experimentally manipulating self-awareness with the use of a mirror could eliminate the tendency for individuals to hypocritically give themselves preferential treatment in a taskassignment exercise (Batson et al., 1999). Even imagining the consequences of one's actions appears to be helpful in dampening immoral behavior (Caruso \& Gino, 2011).

Making the moral content of actions more salient to the self, or reminding individuals of their own personal commitments to be moral, may also encourage more ethical behavior. For example, researchers have found that having individuals sign at the top rather than the bottom of forms makes their personal commitment to the reliability of information they subsequently provide salient, reducing dishonest reporting (Shu et al., 2012). Similarly, making morality salient in general also helps increase ethical behavior. Studies have found that having participants recall the Ten Commandments in advance of a task decreases cheating (Mazar \& Ariely, 2006) and that individuals respond more ethically to those who use a morally relevant quote as part of their email signature and behave more ethically in other ways after exposure to the quote (Desai, 2011). These findings suggest that both internal efforts and external interventions to increase one's self-awareness or the importance of morality to one's self-concept may be effective in reducing unethical behavior and increasing individuals' resistance to conformity pressures.

\subsubsection{Increasing one's sensitivity to moral emotions}

A second method for protecting against influences that sway our moral compass involves understanding the emotions we experience when we face ethical dilemmas. Emotions can 
override rational decision making and influence our behavior across various contexts (Vohs \& Baumeister, 2007; Vohs, Baumeister, \& Loewenstein, 2007), including those with an ethical dimension (Schweitzer \& Gibson, 2008). The emotions that have been most frequently studied in the context of moral choice are negative ones such as shame, guilt, and envy (Haidt, 2003b; Tangney, Stuewig, \& Mashek, 2007). Guilt causes us to want to make amends and expiate negative feeling (Darlington \& Macker, 1966; Regan, Williams, \& Sparling, 1972; Regan, 1971). Though guilt is not a universal consequence of unethical behavior (Ruedy et al., 2013), it can be an instructive emotion that later leads to reparative or altruistic behaviors (Darlington \& Macker, 1966; Freedman, Wallington, \& Bless, 1967). In contrast, shame can lead to less adaptive behaviors such as rumination and aggression (Tangney et al., 1996). Thus, assessing our own emotions when we are considering new actions or reflecting on past ones may be an effective and adaptive way to engage in more moral behavior.

Recently, researchers have also begun to think more carefully about the potential role of positive moral emotions in encouraging ethical behavior (Haidt, 2003a; Haidt et al., 2001). Gratitude, for example, is considered an important motivator of moral behavior (McCullough, Kilpatrick, Emmons, \& Larson, 2001) and is associated empirically with both decreased levels of aggression (DeWall et al., 2012) and increased rates of prosocial behavior (Grant \& Gino, 2010). Other positive emotional states, such as inspiration (Thrash, Elliot, Maruskin, \& Cassidy, 2010) and elevation (Haidt, 2000, 2003a), also increase pro-social behavior, by harnessing the power of positive social relationships that allow us to spend time with people we want to emulate and assist (Algoe \& Haidt, 2009). Harnessing moral emotions also relates to building stronger moral identities, which research on moral exemplars suggests is key to consistently virtuous action (Blasi, 1984; Colby \& Damon, 1993; Oliner \& Oliner, 1988; Reed \& Aquino, 2003). 


\subsubsection{Expanding one's circle of moral regard}

Though our discussion of social categorization and social identity focused on how these social processes facilitate unethical behavior, earlier research drew on the same psychological theories to understand moral behaviors. Emotions appear to interact with our identities to play an important role in how we construct our decision sets, restricting our attention away from moral options or compelling us toward moral action as an inevitability (Monroe, 2001). For example, in her study of the accounts provided by both bystanders and rescuers of Jews in the Holocaust, Monroe (2001) suggests that our moral actions are constrained and directed by social categorization processes and by our perceptions of ourselves in relation to others. Thus, both Holocaust rescuers and bystanders explained their actions in terms of their social identities. Rescuers' identification with broader humanity led them to experience the decision to help as beyond their volition and control: "What else could I do? They were human beings like you and me" (Monroe, 2001, p. 495). Meanwhile, bystanders excluded helping from their possible decision set by viewing themselves as lone individuals who could not possibly stand up to the Nazis (Monroe, 2001, p. 495).

In both cases, group identification constrained behavioral choices. Bystanders made their inaction more psychologically palatable by focusing on saving themselves or their family, representing a narrow circle of moral regard. By contrast, rescuers saw all of humanity as the group to which they owed a moral duty. Their broad sense of moral inclusion (Opotow, 1990) or expansive circle of moral regard (Laham, 2009; Reed \& Aquino, 2003) compelled them to help. If dehumanization is a negative consequence of social categorization, then expanding one's circle of moral regard (Laham, 2009), and practicing other-focused positive emotions (Algoe \& Haidt, 2009; Haidt, 2000, 2003a; Haidt et al., 2001) may help reverse this outcome. Future 
research should grapple with the hard question of how moral emotions and moral identity interact to create or undermine moral commitment. Future research should thus consider interventions that successfully expand individuals' circles of moral regard.

\subsubsection{Practicing self-control}

Our arguments in this chapter suggest that the presence of others who behave dishonestly or to whom we compare unfavorably increases unethical behavior. Thus, a fourth strategy for regaining control of one's moral compass is to better understand why unethical decisions are often tempting and to shore up our resources to resist those temptations. More specifically, when individuals have the opportunity to profit from a dishonest act, whether they behave dishonestly or not depends on how they resolve a motivational conflict between short- and long-term benefits. In the short term, benefits commonly consist of gains that advance one's self-interest. In contrast, acting honestly brings long-term rewards, such as social acceptance and consistency with one's desire to be ethical and viewed positively by others.

Scholars who distinguish between a "want" self (dominated by intuitive, affective, and automatic processes) and a "should" self (dominated by rational, cognitive, and controlled processes) and describe the ethical consequences of these two selves pose a similar argument (Tenbrunsel et al., 2010). Even the simple act of identifying why the "want" self is at odds with the "should" self may lead us to understandings that do not cave so quickly to the visceral desires of the "want" self (Bazerman, Tenbrunsel, \& Wade-Benzoni, 1998; Loewenstein, 1996; Wilson \& Schooler, 1991).

Perhaps more importantly, the resolution of motivational conflicts requires self-control (Mead et al., 2009). Though the literature on self-regulation has dominantly studied what depletes our self-control rather than what builds it up (Baumeister \& Heatherton, 1996; Vohs, 
2006), recent research provides evidence that we can build up our reservoir of self-control through practice (Muraven, 2010; Oaten \& Cheng, 2007) and by finding ways to affirm personally important values (Schmeichel \& Vohs, 2009). Other work is also exploring how selfcontrol can be bolstered through organizational interventions such as task design (Derfler-Rozin, Moore, \& Staats, 2013). Self-control is such an important component of moral behavior that finding additional ways to enhance it demands further exploration.

\subsection{Moving forward}

Resisting the many ways in which our social lives facilitate unethical behavior will always be challenging. Many of these social processes developed for evolutionary reasons and serve positive adaptive functions and social needs. We hand off control of our moral compasses to others all too easily, resulting in behavior that is inconsistent with our best selves (Roberts et al., 2005). Yet the goal of regaining control of our moral compasses is a desirable one for all of us, even in the face of the social processes that facilitate moral neglect, justification, and inaction. Our hope is that we have shed light on how people can become less susceptible to the negative consequences of the social forces we described. We also hope that future research will investigate the questions highlighted in this section to illuminate how people can return their moral compasses to working order.

\section{Conclusion}

In the last few decades, organizational scholars have conducted extensive and insightful research that has deepened our understanding of moral judgment and behavior. This research has tended to focus on intrapersonal processes, providing important insights into individual cognitive limitations that lead people to engage in unethical behavior. However, this body of work offers little information about the social forces that facilitate unethical behavior and the organizational 
conditions that may exacerbate these social influences. Our chapter takes a step toward filling this gap by focusing on interpersonal rather than intrapersonal processes affecting moral judgment and behavior, a topic of increasing interest in organizational scholarship (Bazerman \& Gino, 2012) and of increasing importance in organizational practice (Bazerman \& Tenbrunsel, 2011). Drawing connections between classic research in social psychology and organizational literature on unethical behavior, we have attempted to develop an integrative framework of the facilitators, organizational aggravators, and intrapersonal consequences of unethical judgment and behavior. Our discussion of three social forces that facilitate moral neglect, moral justification, and immoral action may help organize previously disparate bodies of research by highlighting the role of social processes of unethical behavior.

Human beings are social animals who are motivated, influenced, structured, rewarded, and punished every day by other members of their community. Organizations add their own sets of motivations, influences, structures, rewards, and sanctions to encourage and facilitate their objectives. This chapter describes a number of ways in which these social and organizational forces combine to create suboptimal moral outcomes, both individually and collectively. We hope this chapter proves useful in enabling researchers to take an increasingly integrative approach toward developing and testing theory about unethical behavior in organizations. 


\section{Acknowledgments}

We thank Art Brief and Barry Staw for helpful feedback and constructive comments on earlier drafts. Portions of this chapter were presented at the 2010 Annual Meeting of the Academy of Management; we are grateful to symposium participants and attendees for their suggestions. 
Figure 1: How our moral compass can be socially redirected
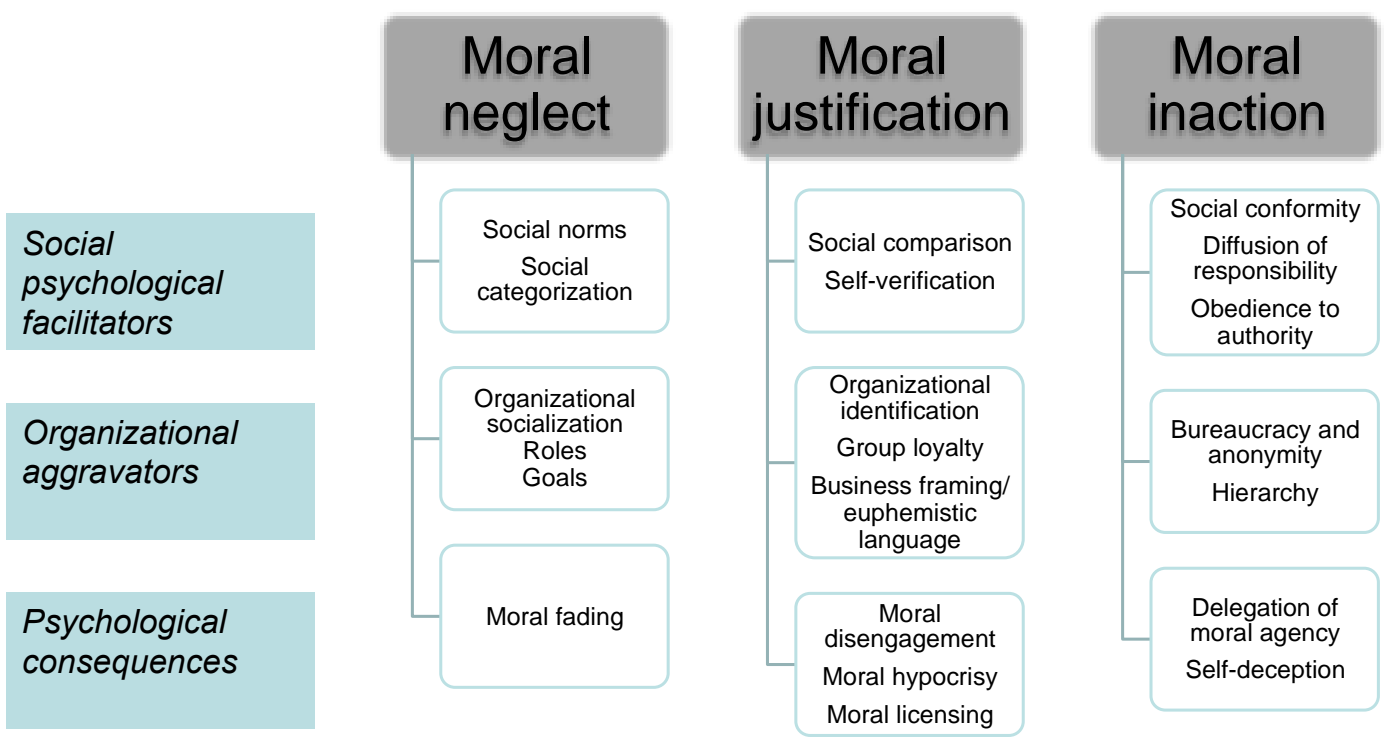


\section{References}

Aczel, A. D. (2001). The riddle of the compass: The invention that changed the world. New York: Harcourt.

Alexander, J. M. (2007). The structural evolution of morality. Cambridge, UK: Cambridge University Press.

Algoe, S. B., \& Haidt, J. (2009). Witnessing excellence in action: The "other-praising" emotions of elevation, gratitude, and admiration. Journal of Positive Psychology, 4, 105-127.

Apel, R., \& Paternoster, R. (2009). Understanding "criminogenic" corporate culture: What whitecollar crime researchers can learn from studies of the adolescent employment-crime relationship. In S. S. Simpson \& D. Weisburd (Eds.), The criminology of white-collar crime (pp. 15-33). New York: Springer.

Aquino, K., \& Reed, A. (2002). The self-importance of moral identity. Journal of Personality and Social Psychology, 83, 1423-1440.

Arendt, H. (1963/1994). Eichmann in Jerusalem: A report on the banality of evil. New York: Penguin.

Asch, S. E. (1951). Effects of group pressure upon the modification and distortion of judgments. In H. Guetzkow (Ed.), Groups, leadership and men: Research in human relations (pp. 177-190). Pittsburgh, PA: Carnegie Press.

Asch, S. E. (1955). Opinions and social pressure. In A. P. Hare, E. F. Borgatta \& R. F. Balles (Eds.), Small groups: Studies in social interaction (pp. 318-324). New York: Alfred A. Knopf.

Ashforth, B. E., \& Anand, V. (2003). The normalization of corruption in organizations. Research in Organizational Behavior, 25, 1-52.

Ayal, S., \& Gino, F. (2011). Honest rationales for dishonest behavior. In M. Mikulincer \& P. R. Shaver (Eds.), The social psychology of morality: Exploring the causes of good and evil (pp. 149-166). Washington, DC: American Psychological Association.

Bakan, J. (2004). The corporation: The pathological pursuit of profit and power. Toronto: Penguin.

Bandura, A. (1973). Social learning theory of aggression. In J. F. Knutson (Ed.), The control of aggression: Implications from basic research (pp. 201-250). Chicago: Aldine Publishing.

Bandura, A. (1990). Mechanisms of moral disengagement. In W. Reich (Ed.), Origins of terrorism: Psychologies, ideologies, states of mind (pp. 161-191). New York: Cambridge University Press.

Bandura, A. (1999). Moral disengagement in the perpetuation of inhumanities. Personality and Social Psychology Review, 3, 193-209.

Bandura, A., Caprara, G. V., \& Zsolnai, L. (2000). Corporate transgressions through moral disengagement. Journal of Human Values, 6, 57-64.

Bandura, A., Ross, D., \& Ross, S. A. (1961). Transmission of aggression through imitation of aggressive models. Journal of Abnormal and Social Psychology, 63, 575-582.

Bandura, A., Ross, D., \& Ross, S. A. (1963). Imitation of film-mediated aggressive models. Journal of Abnormal and Social Psychology, 66, 3-11.

Bandura, A., Underwood, B., \& Fromson, M. E. (1975). Disinhibition of aggression through diffusion of responsibility and dehumanization of victims. Journal of Research in Personality, 9, 253-269. 
Baron, J., \& Ritov, I. (2004). Omission bias, individual differences, and normality. Organizational Behavior and Human Decision Processes, 94, 74-85.

Barsky, A. (2004). The ethical cost of assigned performance goals. (Unpublished doctoral dissertation). Tulane University, New Orleans.

Barsky, A. (2008). Understanding the ethical cost of organizational goal-setting: A review and theory development. Journal of Business Ethics, 81, 63-81.

Bateson, M., Nettle, D., \& Roberts, G. (2006). Cues of being watched enhance cooperation in a real-world setting. Biology Letters, 2, 412-414.

Batson, C. D. (1991). The altruism question: Toward a social-psychological answer. Hillsdale, NJ: Lawrence Erlbaum.

Batson, C. D., Kobrynowicz, D., Dinnerstein, J. L., Kampf, H. C., \& Wilson, A. D. (1997). In a very different voice: Unmasking moral hypocrisy. Journal of Personality and Social Psychology, 72, 1335-1348.

Batson, C. D., Thompson, E. R., Seuferling, G., Whitney, H., \& Strongman, J. A. (1999). Moral hypocrisy: Appearing moral to oneself without being so. Journal of Personality and Social Psychology, 77, 525-537.

Baumeister, R. F., Bratslavsky, E., Finkenauer, C., \& Vohs, K. D. (2001). Bad is stronger than good. Review of General Psychology, 5, 323-370.

Baumeister, R. F., \& Heatherton, T. F. (1996). Self-regulation failure: An overview. Psychological Inquiry, 7, 1-15.

Baumeister, R. F., \& Leary, M. R. (1995). The need to belong: Desire for interpersonal attachments as a fundamental human motivation. Psychological Bulletin, 117, 497-529.

Baumhart, R. (1968). An honest profit: what businessmen say about ethics in business. New York: Holt, Rinehart and Winston.

Bazerman, M. H., \& Gino, F. (2012). Behavioral ethics: Toward a deeper understanding of moral judgment and dishonesty. Annual Review of Law and Social Science, 8, 85-104.

Bazerman, M. H., \& Tenbrunsel, A. E. (2011). Blind spots: Why we fail to do what's right and what to do about it. Princeton, NJ: Princeton University Press.

Bazerman, M. H., Tenbrunsel, A. E., \& Wade-Benzoni, K. (1998). Negotiating with yourself and losing: Making decisions with competing internal preferences. Academy of Management Review, 23, 225-241.

Becker, G. (1957). The economics of discrimination. Chicago: University of Chicago Press.

Bennett, W. J. (1995). The moral compass: Stories for a life's journey. New York: Simon \& Schuster.

Berlin, I., \& Williams, B. (1994). Pluralism and liberalism: A reply. Political Studies, 42, 306309.

Bernard, V. W., Ottenberg, P., \& Redlich, F. (1971). Dehumanization: A composite psychological defense in relation to modern war. In N. Sanford \& C. Comstock (Eds.), Sanctions of evil: Sources of social destructiveness (pp. 102-124). San Francisco: JosseyBass.

Berry, C. M., Sackett, P. R., \& Wiemann, S. A. (2007). A review of recent developments in integrity test research. Personnel Psychology, 60, 270-301.

Bersoff, D. M. (1999a). Explaining unethical behaviour among people motivated to act prosocially. Journal of Moral Education, 28, 413-428.

Bersoff, D. M. (1999b). Why good people sometimes do bad things: Motivated reasoning and unethical behavior. Personality and Social Psychology Bulletin, 25, 28-39. 
Bettenhausen, K., \& Murnighan, J. K. (1985). The emergence of norms in competitive decisionmaking groups. Administrative Science Quarterly, 30, 350-372.

Bird, F. B. (1996). The muted conscience: Moral silence and the practice of ethics in business. Westport, CT: Quorum Books.

Blasi, A. (1984). Moral identity: Its role in moral functioning. In W. Kurtines \& J. Gewirtz (Eds.), Morality, moral behavior and moral development (pp. 128-139). New York: Wiley.

Bohte, J., \& Meier, K. J. (2000). Goal displacement: Assessing the motivation for organizational cheating. Public Administration Review, 60, 173-182.

Brass, D. J., Butterfield, K. D., \& Skaggs, B. C. (1998). Relationships and unethical behavior: A social network perspective. Academy of Management Review, 23, 14-31.

Brenner, S. N., \& Molander, E. A. (1977). Is the ethics of business changing? Harvard Business Review, 55, 57-71.

Brewer, M. B. (1993). Social identity, distinctiveness, and in-group homogeneity. Social Cognition, 11, 150-164.

Brief, A. P., Buttram, R. T., \& Dukerich, J. M. (2001). Collective corruption in the corporate world: Toward a process model. In M. E. Turner (Ed.), Groups at work: Theory and research (pp. 471-499). Mahwah, NJ: Erlbaum.

Brief, A. P., Buttram, R. T., Elliott, J. D., Reizenstein, R. M., \& McCline, R. L. (1995). Releasing the beast: A study of compliance with orders to use race as a selection criterion. Journal of Social Issues, 51, 177-193.

Brief, A. P., Dietz, J., Cohen, R. R., Pugh, S. D., \& Vaslow, J. B. (2000). Just doing business: Modern racism and obedience to authority as explanations for employment discrimination. Organizational Behavior and Human Decision Processes, 81, 72-97.

Brock, T. C., \& Buss, A. H. (1964). Effects of justification for aggression and communication with the victim on post-aggression dissonance. Journal of Abnormal and Social Psychology, 68, 403-412.

Brown, M. E., Treviño, L. K., \& Harrison, D. A. (2005). Ethical leadership: A social learning perspective for construct development and testing. Organizational Behavior and Human Decision Processes, 97, 117-134.

Bryan, J. H., \& Test, M. A. (1967). Models and helping: Naturalistic studies in aiding behavior. Journal of Personality and Social Psychology, 6, 400-407.

Burger, J. M. (2009). Replicating Milgram: Would people still obey today? American Psychologist, 64, 1-11.

Buss, A. H., \& Brock, T. C. (1963). Repression and guilt in relation to aggression. Journal of Abnormal and Social Psychology, 66, 345-350.

Butterfield, K. D., Treviño, L. K., \& Weaver, G. R. (2000). Moral awareness in business organizations: Influence of issue-related and social context factors. Human Relations, 53, 981-1018.

Cain, D. M., Loewenstein, G., \& Moore, D. A. (2011). When sunlight fails to disinfect: Understanding the perverse effects of disclosing conflicts of interest. Journal of Consumer Research, 37, 836-857.

Caruso, E. M., \& Gino, F. (2011). Blind ethics: Closing one's eyes polarizes moral judgments and discourages dishonest behavior. Cognition, 118, 280-285. 
Chance, Z., Norton, M. I., Gino, F., \& Ariely, D. (2011). Temporal view of the costs and benefits of self-deception. Proceedings of the National Academy of Sciences, 108, (Supplement 3) 15655-15959.

Chugh, D., Bazerman, M. H., \& Banaji, M. R. (2005). Bounded ethicality as a psychological barrier to recognizing conflicts of interest. In D. A. Moore, D. M. Cain, G. Loewenstein \& M. H. Bazerman (Eds.), Conflicts of interest: Challenges and solutions in business, law, medicine, and public policy (pp. 74-95). New York: Cambridge University Press.

Cialdini, R. B. (1984). Influence: The psychology of persuasion. New York: William Morrow.

Cialdini, R. B., Kallgren, C. A., \& Reno, R. R. (1991). A focus theory of normative conduct: A theoretical refinement and reevaluation of the role of norms in human behavior. Advances in Experimental Social Psychology, 24, 201-234.

Cialdini, R. B., Reno, R. R., \& Kallgren, C. A. (1990). A focus theory of normative conduct: Recycling the concept of norms to reduce littering in public places. Journal of Personality and Social Psychology, 58, 1015-1026.

Cikara, M., Farnsworth, R. A., Harris, L. T., \& Fiske, S. T. (2010). On the wrong side of the trolley track: Neural correlates of relative social valuation. Social Cognitive and Affective Neuroscience, 5, 404-413.

Claybourn, M. (2011). Relationships between moral disengagement, work characteristics and workplace harassment. Journal of Business Ethics, 100, 283-301.

Clinard, M. B., \& Quinney, R. (1973). Criminal behaviour systems: A typology (2nd ed.). New York: Holt, Rinehart and Winston.

Coffee, J. C. (1981). No soul to damn, no body to kick: An unscandalized inquiry into the problem of corporate punishment. Michigan Law Review, 79, 386-457.

Colby, A., \& Damon, W. (1993). The uniting of self and morality in the development of extraordinary moral commitment. In G. G. Noam \& T. E. Wren (Eds.), The moral self (pp. 149-174). Camridge, MA: MIT Press.

Coleman, J. W., \& Ramos, L. L. (1998). Subcultures and deviant behavior in the organizational context. In P. A. Bamberger \& W. J. Sonnenstuhl (Eds.), Research in the Sociology of Organizations (Vol. 15, pp. 3-34). Stamford, CT: JAI Press.

Covey, M. K., Saladin, S., \& Killen, P. J. (1989). Self-monitoring, surveillance, and incentive effects on cheating. Journal of Social Psychology, 129, 673-679.

Cushman, F., Knobe, J., \& Sinnott-Armstrong, W. (2008). Moral appraisals affect doing/allowing judgments. Cognition, 108, 281-289.

Dabney, D. (1995). Neutralization and deviance in the workplace: Theft of supplies and medicines by hospital nurses. Deviant Behavior, 16, 313-331.

Dana, J., Weber, R., \& Kuang, J. (2007). Exploiting moral wiggle room: experiments demonstrating an illusory preference for fairness. Economic Theory, 33, 67-80.

Darley, J. M., \& Latané, B. (1968). Bystander intervention in emergencies: Diffusion of responsibility. Journal of Personality and Social Psychology, 8, 377-383.

Darlington, R. B., \& Macker, C. E. (1966). Displacement of guilt-produced altruistic behavior. Journal of Personality and Social Psychology, 4, 442-443.

de Oliveira-Souza, R., Hare, R. D., Bramati, I. E., Garrido, G. J., F., A. I., Tovar-Moll, F., \& Moll, J. (2008). Psychopathy as a disorder of the moral brain: Fronto-temporo-limbic grey matter reductions demonstrated by voxel-based morphometry. NeuroImage, 40, 1202-1213. 
de Waal, F. (2006). Primates and Philosophers: How Morality Evolved. Princeton, NJ: Princeton University Press.

Deci, E. L., \& Ryan, R. M. (1985). Intrinsic motivation and self-determination in human behavior. New York: Plenum.

DePalma, M. T., Madey, S. F., \& Bornschein, S. (1995). Individual differences and cheating behavior: Guilt and cheating in competitive situations. Personality and Individual Differences, 18, 761-769.

Derfler-Rozin, R., Moore, C., \& Staats, B. (2013). Enhancing ethical behavior through sequential task variety: Building self-control through work design. Manuscript submitted for publication.

Desai, S. D. (2011). Warding off organizational vampires: Moral cues as a necklace of garlic. (Unpublished doctoral dissertation). University of Utah, Salt Lake City.

Detert, J. R., Treviño, L. K., \& Sweitzer, V. L. (2008). Moral disengagement in ethical decision making. Journal of Applied Psychology, 93, 374-391.

DeWall, C. N., Lambert, N. M., Pond, R. S., Kashdan, T. B., \& Fincham, F. D. (2012). A grateful heart is a nonviolent heart. Social Psychological and Personality Science, 3, 232240.

Diener, E., Fraser, S. C., \& Beaman, A. L. (1976). Effects of deindividuation variables on stealing among Halloween trick-or-treaters. Journal of Personality and Social Psychology, 33, 178-183.

Diener, E., \& Wallbom, M. (1976). Effects of self-awareness on antinormative behavior. Journal of Research in Personality, 10, 107-111.

Doherty, K., Weigold, M. F., \& Schlenker, B. R. (1990). Self-serving interpretations of motives. Personality and Social Psychology Bulletin, 16, 485-495.

Doris, J. M. (2002). Lack of character: Personality and moral behavior. Cambridge, UK: Cambridge University Press.

Dowd, M. (2009, May 3). How character corrodes, New York Times. Retrieved from http://www.nytimes.com/2009/05/03/opinion/03dowd.html?em.

Dozier, J. B., \& Miceli, M. P. (1985). Potential predictors of whistle-blowing: A prosocial behavior perspective. Academy of Management Review, 10, 823-836.

Duffy, M. K., Aquino, K., Tepper, B. J., Reed, A., \& O'Leary-Kelly, A. (2005). Moral disengagement and social identification: When does being similar result in harm doing? Paper presented at the Academy of Management Annual Conference, Honolulu, Hawaii.

Duffy, M. K., Scott, K. L., Shaw, J. D., Tepper, B. J., \& Aquino, K. (2012). A social context model of envy and social undermining. Academy of Management Journal, 55, 643-666.

Duffy, M. K., \& Shaw, J. D. (2000). The Salieri syndrome consequences of envy in groups. Small Group Research, 31, 3-23.

Effron, D. A., Cameron, J. S., \& Monin, B. (2009). Endorsing Obama licenses favoring Whites. Journal of Experimental Social Psychology, 45, 590-593.

Effron, D. A., \& Monin, B. (2010). Letting people off the hook: When do good deeds excuse transgressions? Personality and Social Psychology Bulletin, 36, 1618-1634.

Ehrhart, M. G. (2004). Leadership and procedural justice climate as antecedents of unit-level organizational citizenship behavior. Personnel Psychology, 57, 61-94.

Eibach, R. P., Libby, L. K., \& Ehrlinger, J. (2009). Priming family values: How being a parent affects moral evaluations of harmless but offensive acts. Journal of Experimental Social Psychology, 45, 1160-1163. 
Eisenberg, N. (2000). Emotion, regulation, and moral development. Annual Review of Psychology, 51, 665-697.

Felps, W., Mitchell, T. R., \& Byington, E. (2006). How, when, and why bad apples spoil the barrel: Negative group members and dysfunctional groups. Research in Organizational Behavior, 27, 175-222.

Fenigstein, A., Scheier, M. F., \& Buss, A. H. (1975). Public and private self-consciousness: Assessment and theory. Journal of Consulting and Clinical Psychology, 43, 522.

Ferraro, F., Pfeffer, J., \& Sutton, R. I. (2005). Economics language and assumptions: How theories can become self-fulfilling. Academy of Management Review, 30, 8-24.

Festinger, L. (1954). A theory of social comparison processes. Human Relations, 7, 117-140.

Finn, K. V., \& Frone, M. R. (2004). Academic performance and cheating: Moderating role of school identification and self-efficacy. Journal of Educational Research, 97, 115-121.

Fiske, S. T., Harris, L. T., \& Cuddy, A. J. C. (2004). Why ordinary people torture enemy prisoners. Science, 306, 1482-1483.

Fitzsimons, G. i. M., \& Bargh, J. A. (2003). Thinking of you: Nonconscious pursuit of interpersonal goals associated with relationship partners. Journal of Personality and Social Psychology, 84, 148-164.

Flynn, F. J., \& Wiltermuth, S. S. (2010). Who's with me? False consensus, brokerage, and ethical decision making in organizations. Academy of Management Journal, 53, 1074-1089.

Freedman, J. L., Wallington, S. A., \& Bless, E. (1967). Compliance without pressure: The effect of guilt. Journal of Personality and Social Psychology, 7, 117-124.

Frey, B. S. (1992). Tertium datur: Pricing, regulating and intrinsic motivation. Kyklos, 45, 161184.

Frey, B. S., \& Stutzer, A. (2006). Environmental morale and motivation. Working Paper, Institute for Empirical Research in Economics. University of Zurich.

Froming, W. J., Walker, G. R., \& Lopyan, K. J. (1982). Public and private self-awareness: When personal attitudes conflict with societal expectations. Journal of Experimental Social Psychology, 18, 476-487.

Galinsky, A. D., \& Ku, G. (2004). The effects of perspective-taking on prejudice: The moderating role of self-evaluation. Personality and Social Psychology Bulletin, 30, 594604.

Galinsky, A. D., \& Moskowitz, G. B. (2000). Perspective-taking: Decreasing stereotype expression, stereotype accessibility, and in-group favoritism. Journal of Personality and Social Psychology, 78, 708.

Gino, F., Ayal, S., \& Ariely, D. (2009). Contagion and differentiation in unethical behavior: The effect of one bad apple on the barrel. Psychological Science, 20, 393-398.

Gino, F., \& Bazerman, M. H. (2009). When misconduct goes unnoticed: The acceptability of gradual erosion in others' unethical behavior. Journal of Experimental Social Psychology, 45, 708-719.

Gino, F., \& Galinsky, A. D. (2012). Vicarious dishonesty: When psychological closeness creates distance from one's own moral compass. Organizational Behavior and Human Decision Processes, 119, 15-26.

Gino, F., Gu, J., \& Zhong, C.-B. (2009). Contagion or restitution? When bad apples can motivate ethical behavior. Journal of Experimental Social Psychology, 45, 1299-1302.

Gino, F., \& Pierce, L. (2009). Dishonesty in the name of equity. Psychological Science, 20, 1153-1160. 
Gino, F., \& Pierce, L. (2010). Robin Hood under the hood: Wealth-based discrimination in illicit customer help. Organization Science, 21, 1176-1194.

Gino, F., Shu, L. L., \& Bazerman, M. H. (2010). Nameless + harmless = blameless: When seemingly irrelevant factors influence judgment of (un)ethical behavior. Organizational Behavior and Human Decision Processes, 111, 93-101.

Gioia, D. A. (1992). Pinto fires and personal ethics: A script analysis of missed opportunities. Journal of Business Ethics, 11, 379-389.

Gioia, D. A., \& Poole, P. P. (1984). Scripts in organizational behavior. Academy of Management Review, 9, 449-459.

Goldstein, N. J., Cialdini, R. B., \& Griskevicius, V. (2008). A room with a viewpoint: Using social norms to motivate environmental conservation in hotels. Journal of Consumer Research, 35, 472-482.

Goldstein, N. J., Martin, S. J., \& Cialdini, R. B. (2008). Yes!: 50 scientifically proven ways to be persuasive. New York: Simon and Schuster,.

Grant, A. (2007). Relational job design and the motivation to make a prosocial difference. Academy of Management Review, 32, 393-417.

Grant, A. M., \& Gino, F. (2010). A little thanks goes a long way: Explaining why gratitude expressions motivate prosocial behavior. Journal of Personality and Social Psychology, 98, 946-955.

Grant, R. W. (2012). Strings attached: Untangling the ethics of incentives. Princeton, NJ: Princeton University Press.

Greenberg, J. (1990). Employee theft as a reaction to underpayment inequity: The hidden cost of pay cuts. Journal of Applied Psychology, 75, 561-568.

Greene, E. J., \& Darley, J. M. (1998). Effects of necessary, sufficient, and indirect causation on judgments of criminal liability. Law and Human Behavior, 22, 429-451.

Gross, E. (1978). Organizational crime: A theoretical perspective. Studies in Symbolic Interaction, 1, 55-85.

Gross, E. (1980). Organizational structure and organizational crime. In G. Geis \& E. Stotland (Eds.), White collar crime: Theory and research (pp. 52-76). Beverly Hills, CA: Sage.

Gunia, B. C., Sivanathan, N., \& Galinsky, A. D. (2009). Vicarious entrapment: Your sunk costs, my escalation of commitment. Journal of Experimental Social Psychology, 45, 12381244.

Guzzo, R. A., \& Dickson, M. W. (1996). Teams in organizations: Recent research on performance and effectiveness. Annual Review of Psychology, 47, 307-338.

Haidt, J. (2000). The positive emotion of elevation. Prevention \& Treatment, 3, np.

Haidt, J. (2003a). Elevation and the positive psychology of morality. In C. L. M. Keyes \& J. Haidt (Eds.), Flourishing: Positive psychology and the life well-lived (pp. 275-289). Washington DC: American Psychological Association.

Haidt, J. (2003b). The moral emotions. In R. J. Davidson, K. R. Sherer \& H. H. Goldsmith (Eds.), Handbook of affective sciences (pp. 852-870). New York: Oxford University Press.

Haidt, J., Algoe, S., Meijer, Z., Tam, A., \& Chandler, E. C. (2001). Elevation: an emotion that makes people want to do good deeds. Unpublished manuscript, University of Virginia. Carlottesville, VA.

Haidt, J., \& Bjorklund, F. (2008). Social intuitionists answer six questions about moral psychology. In W. Sinnott-Armstrong (Ed.), Moral psychology: The cognitive science of morality: Intuition and Diversity (Vol. 2, pp. 181-217). Cambridge, MA: MIT Press. 
Haidt, J., \& Graham, J. (2007). When morality opposes justice: Conservatives have moral intuitions that liberals may not recognize. Social Justice Research, 20, 98-116.

Haley, K. J., \& Fessler, D. M. T. (2005). Nobody's watching?: Subtle cues affect generosity in an anonymous economic game. Evolution and Human Behavior, 26, 245-256.

Harris, L. T., \& Fiske, S. T. (2006). Dehumanizing the lowest of the low: Neuroimaging responses to extreme out-groups. Psychological Science, 17, 847-853.

Haslam, N. (2006). Dehumanization: An integrative review. Personality and Social Psychology Review, 10, 252-264.

Haslam, S. A., \& Reicher, S. (2006). Stressing the group: Social identity and the unfolding dynamics of responses to stress. Journal of Applied Psychology, 91, 1037-1052.

Hatfield, E., Cacioppo, J. T., \& Rapson, R. L. (1994). Emotional contagion. New York: Cambridge University Press.

Heck, W. P. (1992). Police who snitch: Deviant actors in a secret society. Deviant Behavior: An Interdisciplinary Journal, 13, 253-270.

Hersh, S. (2004). Chain of command: The road from 9/11 to Abu Ghraib. New York: HarperCollins

Hicks, D. J. (1968). Effects of co-observer's sanctions and adult presence on imitative aggression. Child Development, 39, 303-309.

HM Revenue and Customs. (2011, March). Tackling tax avoidance. London, UK: HM Treasury Retrieved from http://cdn.hm-treasury.gov.uk/2011budget taxavoidance.pdf.

Hogg, M. A. (2007). Social categorization, depersonalization, and group behavior. In M. A. Hogg \& S. Tindale (Eds.), Blackwell Handbook of Social Psychology: Group Processes (pp. 56-85). Oxford, UK: Blackwell.

Høgh-Oleson, H. (2010). Human morality and sociality: Evolutionary and comparative perspectives. Basingstoke, NY: Palgrave Macmillan.

Hollinger, R. C., Slora, K. B., \& Terris, W. (1992). Deviance in the fast-food restaurant: Correlates of employee theft, altruism, and counterproductivity. Deviant Behavior, 13, $155-184$.

Hornstein, H. A., Fisch, E., \& Holmes, M. (1968). Influence of a model's feeling about his behavior and his relevance as a comparison other on observers' helping behavior. Journal of Personality and Social Psychology, 10, 222-226.

Hughes, E. C. (1937). Institutional office and the person. American Journal of Sociology, 43, 404-413.

Huntsman, J. M. (2010). Winners play by the rules: Keep your moral compass. Upper Saddle River, N.J.: FTPress.

Hutton, D. G., \& Baumeister, R. F. (1992). Self-awareness and attitude change: Seeing oneself on the central route to persuasion. Personality and Social Psychology Bulletin, 18, 68-75.

Jackall, R. (1988). Moral mazes: The world of corporate managers. New York: Oxford University Press.

Jackson, P. L., Brunet, E., Meltzoff, A. N., \& Decety, J. (2006). Empathy examined through the neural mechanisms involved in imagining how I feel versus how you feel pain. Neuropsychologia, 44, 752-761.

Jacob, B. A., \& Levitt, S. D. (2003). Rotten apples: An investigation of the prevalence and predictors of teacher cheating. Quarterly Journal of Economics, 118, 843-878.

Janis, I. L. (1972). Victims of groupthink. Boston: Houghton Mifflin

Jeter, L. W. (2003). Disconnected: Deceit and betrayal at WorldCom. Hoboken, NJ: Wiley. 
Jones, D. (2000). Group nepotism and human kinship. Current Anthropology, 41, 779-809.

Jones, T. M. (1991). Ethical decision making by individuals in organizations: An issuecontingent model. Academy of Management Review, 16, 366-395.

Kelman, H. C. (1973). Violence without moral restraint: Reflections on the dehumanization of victims and victimizers. Journal of Social Issues, 29, 25-61.

Kelman, H. C., \& Hamilton, V. L. (1989). Crimes of obedience. New Haven: Yale University Press.

Kemper, T. D. (1966). Representative roles and the legitimation of deviance. Social Problems, 13, 288-298.

Kern, M. C., \& Chugh, D. (2009). Bounded ethicality: The perils of loss framing. Psychological Science, 20, 378-384.

Kerr, S. (1975). On the folly of rewarding A, while hoping for B. Academy of Management Journal, 18, 769-783.

Kish-Gephart, J. J., Harrison, D. A., \& Treviño, L. K. (2010). Bad apples, bad cases, and bad barrels: Meta-analytic evidence about sources of unethical decisions at work. Journal of Applied Psychology, 95, 1-31.

Klass, E. T. (1978). Psychological effects of immoral actions: The experimental evidence. Psychological Bulletin, 85, 756-771.

Kouchaki, M. (2011). Vicarious moral licensing: The influence of others' past moral actions on moral behavior. Journal of Personality and Social Psychology, 101, 702-715.

Kramer, M. (1990). The moral logic of Hizballah. In W. Reich (Ed.), Origins of terrorism: Psychologies, ideologies, theologies, states of mind (pp. 131-157). Cambridge, England: Cambridge University Press.

Kramer, R. M., \& Messick, D. M. (1996). Ethical cognition and the framing of organizatinal dilemmas: Decision makers as intuitive lowyers. In D. M. Messick \& A. E. Tenbrunsel (Eds.), Codes of conduct: Behavioural research into business ethics (pp. 59-85). New York: Sage.

Kreps, T., \& Monin, B. (2011). 'Doing well by doing good'? Ambivalent moral framing in organizations. Research in Organizational Behavior, 31, 99-123.

Kulik, B., O'Fallon, M., \& Salimath, M. (2008). Do competitive environments lead to the rise and spread of unethical behavior? Parallels from Enron. Journal of Business Ethics, 83, 703-723.

Labaton, S. (2004, October 7). Chief says Fannie Mae did nothing wrong, New York Times. Retrieved from http://www.nytimes.com/2004/10/07/business/07fannie.html?pagewanted=print\&position 三.

Labianca, G., Brass, D. J., \& Gray, B. (1998). Social networks and perceptions of intergroup conflict: The role of negative relationships and third parties. Academy of Management Journal, 41, 55-67.

Laham, S. M. (2009). Expanding the moral circle: Inclusion and exclusion mindsets and the circle of moral regard. Journal of Experimental Social Psychology, 45, 250-253.

Latané, B., \& Darley, J. M. (1968). Group inhibition of bystander intervention in emergencies. Journal of Personality and Social Psychology, 10, 215-221.

Latané, B., \& Darley, J. M. (1970). The unresponsive bystander: Why doesn't he help? New York: Appleton-Century-Crofts. 
Leach, C. W., Ellemers, N., \& Barreto, M. (2007). Group virtue: The importance of morality (vs. competence and sociability) in the positive evaluation of in-groups. Journal of Personality and Social Psychology, 93, 234-249.

Leary, M. R. (2007). Motivational and emotional aspects of the self. Annual Review of Psychology, 58, 317-344.

Lewis, M. (1989). Liar's poker. New York: Penguin.

Liberman, V., Samuels, S. M., \& Ross, L. (2004). The name of the game: Predictive power of reputations versus situational labels in determining prisoner's dilemma game moves. Personality and Social Psychology Bulletin, 30, 1175-1185.

Locke, E. A., \& Latham, G. P. (2002). Building a practically useful theory of goal setting and task motivation: A 35-year odyssey. American Psychologist, 57, 705-717.

Loewenstein, G. (1996). Out of control: Visceral influences on behavior. Organizational Behavior and Human Decision Processes, 65, 272-292.

Lohr, S. (2004, June 4). Ex-executives at symbol are indicted, New York Times. Retrieved from http://www.nytimes.com/2004/06/04/business/ex-executives-at-symbol-areindicted.html?pagewanted $=$ all $\&$ src $=$ pm.

MacLean, T. (2001). Thick as thieves: A socially embedded model of rule breaking in organizations. Business and Society, 40, 167-196.

Magee, J. C., \& Galinsky, A. D. (2008). Social hierarchy: The self-reinforcing nature of power and status. Academy of Management Annals, 2, 351-398.

Magee, J. C., Kilduff, G. J., \& Heath, C. (2011). On the folly of principal's power: Managerial psychology as a cause of bad incentives. Research in Organizational Behavior, 31, 25-41.

March, J. G. (1994). A primer on decision-making: How decisions happen. New York: The Free Press.

Margolis, J. (2009). The responsibilty gap. The Hedgehog Review, 11, 41-53.

Mars, G. (1982). Cheats at work: An anthropology of workplace crime. London: George Allen \& Unwin.

Matza, D. (1964). Delinquency and drift. New York: John Wiley \& Sons.

Mayer, D. M., Aquino, K., Greenbaum, R. L., \& Kuenzi, M. (2012). Who displays ethical leadership and why does it matter? An examination of antecedents and consequences of ethical leadership. Academy of Management Journal, 55, 151-171.

Mayer, D. M., Kuenzi, M., Greenbaum, R., Bardes, M., \& Salvador, R. (2009). How low does ethical leadership flow? Test of a trickle-down model. Organizational Behavior and Human Decision Processes, 108, 1-13.

Mazar, N., Amir, O., \& Ariely, D. (2008). The dishonesty of honest people: A theory of selfconcept maintenance. Journal of Marketing Research, 45, 633-644.

Mazar, N., \& Ariely, D. (2006). Dishonesty in everyday life and its policy implications. Journal of Public Policy and Marketing, 25, 117-126.

McCullough, M. E., Kilpatrick, S. D., Emmons, R. A., \& Larson, D. B. (2001). Is gratitude a moral affect? Psychological Bulletin, 127, 249-266.

McGraw, K. M. (1987). Guilt following transgression: An attribution of responsibility approach. Journal of Personality and Social Psychology, 53, 247-256.

Mead, N. L., Baumeister, R. F., Gino, F., Schweitzer, M. E., \& Ariely, D. (2009). Too tired to tell the truth: Self-control resource depletion and dishonesty. Journal of Experimental Social Psychology, 45, 594-597. 
Merritt, A. C., Effron, D. A., \& Monin, B. (2010). Moral self-licensing: When being good frees us to be bad. Social and Personality Psychology Compass, 4, 344-357.

Milgram, S. (1963). Behavioral study of obedience. Journal of Abnormal and Social Psychology, 67, 371-378.

Milgram, S. (1974). Obedience to authority: An experimental view. New York: Harper \& Row.

Miller, D. T., \& Effron, D. A. (2010). Psychological license: When it is needed and how it functions. Advances in Experimental Social Psychology, 43, 115-155.

Miller, R. S. (1987). Empathic embarrassment: Situational and personal determinants of reactions to the embarrassment of another. Journal of Personality and Social Psychology, 53,1061 .

Mohliver, A. C. (2012). The legitimacy of corrupt practices: geography of auditors advice and backdating of stock option grants. Paper presented at the Academy of Management Annual Meeting, Boston, MA.

Monin, B. (2007). Holier than me? Threatening social comparison in the moral domain. Revue internationale de psychologie sociale, 53-68.

Monin, B., \& Jordan, A. H. (2009). Dynamic moral identity: A social psychological perspective. In D. Narvaez \& D. Lapsley (Eds.), Personality, identity, and character: Explorations in moral psychology (pp. 341-354). Cambridge, MA: Cambridge University Press.

Monin, B., \& Miller, D. T. (2001). Moral credentials and the expression of prejudice. Journal of Personality and Social Psychology, 81, 33-43.

Monroe, K. R. (2001). Morality and a sense of self: The importance of identity and categorization for moral action. American Journal of Political Science, 45, 491-507.

Moore, C. (2009). Psychological perspectives on corruption. In D. De Cremer (Ed.), Psychological perspectives on ethical behavior and decision making (pp. 35-71).

Charlotte, NC: Information Age Publishing.

Moore, C., Detert, J. R., Treviño, L. K., Baker, V. L., \& Mayer, D. M. (2012). Why employees do bad things: Moral disengagement and unethical organizational behavior. Personnel Psychology, 65, 1-48.

Moore, D. A., Tetlock, P. E., Tanlu, L., \& Bazerman, M. H. (2006). Conflicts of interest and the case of auditor independence: Moral seduction and strategic issue cycling. Academy of Management Review, 31, 10-29.

Moore, M. S. (1993). Act and crime: The philosophy of action and its implications for criminal law. Oxford: Oxford University Press.

Moran, S., \& Schweitzer, M. E. (2008). When better is worse: Envy and the use of deception. Negotiation and Conflict Management Research, 1, 3-29.

Muraven, M. (2010). Building self-control strength: Practicing self-control leads to improved self-control performance. Journal of Experimental Social Psychology, 46, 465-468.

Murnighan, J. K., Cantelon, D. A., \& Elyashiv, T. (2001). Bounded personal ethics and the tap dance of real estate agency. In J. A. Wagner, J. M. Bartunek \& K. D. Elsbach (Eds.), Advances in Qualitative Organizational Research (Vol. 3, pp. 1-40). New York: Elsevier/JAI.

Murray, S. L., Rose, P., Bellavia, G. M., Holmes, J. G., \& Kusche, A. G. (2002). When rejection stings: How self-esteem constrains relationship-enhancement processes. Journal of Personality and Social Psychology, 83, 556.

Near, J. P., \& Miceli, M. P. (1996). Whistle-blowing: Myth and reality. Journal of Management, 22, 507-526. 
Newcomb, T. M. (1961). The acquaintance process. New York: Holt, Rinehard and Winston.

Newstead, S. E., Franklyn-Stokes, A., \& Armstead, P. (1996). Individual differences in student cheating. Journal of Educational Psychology, 88, 229-241.

Nosanchuk, T. A., \& Lightstone, J. (1974). Canned laughter and public and private conformity. Journal of Personality and Social Psychology, 29, 153-156.

Oaten, M., \& Cheng, K. (2007). Improvements in self-control from financial monitoring. Journal of Economic Psychology, 28, 487-501.

Okel, E., \& Mosher, D. L. (1968). Changes in affective states as a function of guilt over aggressive behavior. Journal of Consulting and Clinical Psychology, 32, 265-270.

Oliner, S. P., \& Oliner, P. M. (1988). The altruistic personality: Rescuers of Jews in Nazi Europe. New York: The Free Press.

Opotow, S. (1990). Moral exclusion and injustice: An introduction. Journal of Social Issues, 46, $1-20$.

Ordóñez, L. D., Schweitzer, M. E., Galinsky, A. D., \& Bazerman, M. H. (2009). Goals gone wild: The systematic side effects of overprescribing goal setting. [Article]. Academy of Management Perspectives, 23, 6-16.

Pasha, S. (2006, March 6). Enron trial: Defense skewers Fastow on the stand, CNNMoney.com. Retrieved from http://money.cnn.com/2006/03/08/news/newsmakers/enron/index.htm.

Pershing, J. L. (2002). Whom to betray? Self-regulation of occupational misconduct at the United States Naval Academy. Deviant Behavior, 23, 149-175.

Perugini, M., \& Leone, L. (2009). Implicit self-concept and moral action. Journal of Research in Personality, 43, 747-754.

Pillutla, M. M., \& Chen, X.-P. (1999). Social norms and cooperation in social dilemmas: The effects of context and feedback. Organizational Behavior and Human Decision Processes, 78, 81-103.

Pruitt, D. G., \& Kimmel, M. J. (1977). Twenty years of experimental gaming: Critique, synthesis, and suggestions for the future. Annual Review of Psychology, 28, 363-392.

Pryor, J. B., Gibbons, F. X., Wicklund, R. A., Fazio, R. H., \& Hood, R. (1977). Self-focused attention and self-report validity. Journal of Personality, 45, 513-527.

Rai, T. S., \& Fiske, A. P. (2011). Moral psychology is relationship regulation: Moral motives for unity, hierarchy, equality, and proportionality. Psychological Review, 118, 57-75.

Rapoport, D. C., \& Alexander, Y. (Eds.). (1982). The morality of terrorism: Religious and secular justification. Elmsford, NY: Pergamon Press.

Raven, B. H. (1974). The Nixon Group. Journal of Social Issues, 30, 297-320.

Reed, A., II, \& Aquino, K. F. (2003). Moral identity and the expanding circle of moral regard toward out-groups. Journal of Personality and Social Psychology, 84, 1270-1286.

Regan, D. T., Williams, M., \& Sparling, S. (1972). Voluntary expiation of guilt: A field experiment. Journal of Personality and Social Psychology, 24, 42-45.

Regan, J. W. (1971). Guilt, perceived injustice, and altruistic behavior. Journal of Personality and Social Psychology, 18, 124-132.

Reno, R. R., Cialdini, R. B., \& Kallgren, C. A. (1993). The transsituational influence of social norms. Journal of Personality and Social Psychology, 64, 104-112.

Rest, J. R. (1986). Moral development: Advances in research and theory. Minneapolis: University of Minnesota Press. 
Reynolds, S. J. (2006). Moral awareness and ethical predispositions: Investigating the role of individual differences in the recognition of moral issues. Journal of Applied Psychology, 91, 233-243.

Reynolds, S. J. (2008). Moral attentiveness: Who pays attention to the moral aspects of life? Journal of Applied Psychology, 93, 1027-1041.

Ring, K., Wallston, K., \& Corey, M. (1970). Mode of debriefing as a factor affecting subjective reaction to a Milgram type obedience experiment: An ethical inquiry. Representative Research in Social Psychology, 1, 67-88.

Roberts, L. M., Dutton, J. E., Spreitzer, G. M., Heaphy, E. D., \& Quinn, R. E. (2005). Composing the reflected best-self portrait: Building pathways for becoming extraordinary in work organizations. Academy of Management Review, 30, 712-736.

Robinson, D. T., \& Smith-Lovin, L. (1992). Selective interaction as a strategy for identity maintenance: An affect control model. Social Psychology Quarterly, 55, 12-28.

Rorty, R. (2001). Justice as a larger loyalty. In M. Festenstein \& S. Thompson (Eds.), Critical dialogues (pp. 223-237). Malden, MA: Blackwell.

Ross, L., Greene, D., \& House, P. (1977). The "false consensus effect": An egocentric bias in social perception and attribution processes. Journal of Experimental Social Psychology, 13, 279-301.

Rothschlid, J., \& Miethe, T. D. (1999). Whistle-blower disclosures and management retaliation. Work and Occupations, 26, 107-128.

Ruedy, N., \& Schweitzer, M. (2010). In the moment: The effect of mindfulness on ethical decision making. Journal of Business Ethics, 95, 73-87.

Ruedy, N. E., Moore, C., Gino, F., \& Schweitzer, M. E. (2013). The cheater's high: The unexpected affective benefits of unethical behavior. Manuscript submitted for publication. .

Sabini, J., \& Silver, M. (1982). Moralities of everyday life. Oxford, New York: Oxford University Press.

Sachdeva, S., Iliev, R., \& Medin, D. L. (2009). Sinning saints and saintly sinners: The paradox of moral self-regulation. Psychological Science, 20, 523-528.

Salovey, P., \& Rodin, J. (1984). Some antecedents and consequences of social-comparison jealousy. Journal of Personality and Social Psychology, 47, 780-792.

Scheier, M. F., \& Carver, C. S. (1980). Private and public self-attention, resistance to change, and dissonance reduction. Journal of Personality and Social Psychology, 39, 390.

Schmeichel, B. J., \& Vohs, K. (2009). Self-affirmation and self-control: Affirming core values counteracts ego depletion. Journal of Personality and Social Psychology, 96, 770-782.

Schweitzer, M. E., \& Gibson, D. E. (2008). Fairness, feelings, and ethical decision-making: Consequences of violating community standards of fairness. Journal of Business Ethics, 77, 287-301.

Schweitzer, M. E., Ordóñez, L., \& Douma, B. (2004). Goal setting as a motivator of unethical behavior. Academy of Management Journal, 47, 422-432.

Searcey, D., Young, S., \& Scannell. (2005, July 14). Ebbers is sentenced to 25 years for $\$ 100$ billion WorldCom fraud, Wall Street Journal. Retrieved from http://online.wsj.com/article/0,,SB112126001526184427,00.html.

Sedikides, C., \& Strube, M. J. (1997). Self-evaluation: To thine own self be good, to thine own self be sure, to thine own self be true, and to thine own self be better. Advances in Experimental Social Psychology, 29, 209-269. 
Shah, J. Y., Friedman, R., \& Kruglanski, A. W. (2002). Forgetting all else: On the antecedents and consequences of goal shielding. Journal of Personality and Social Psychology, 83, 1261-1280.

Shalvi, S., Dana, J., Handgraaf, M. J. J., \& De Dreu, C. K. W. (2011). Justified ethicality: Observing desired counterfactuals modifies ethical perceptions and behavior. Organizational Behavior and Human Decision Processes, 115, 181-190.

Shariff, A. F., \& Norenzayan, A. (2007). God Is watching you: Priming God concepts increases prosocial behavior in an anonymous economic game. [Article]. Psychological Science, 18, 803-809.

Shu, L. L., \& Gino, F. (2012). Sweeping dishonesty under the rug: How unethical actions lead to forgetting of moral rules. Journal of Personality and Social Psychology, 102, 1164-1177.

Shu, L. L., Gino, F., \& Bazerman, M. H. (2011). Dishonest deed, clear conscience: When cheating leads to moral disengagement and motivated forgetting. Personality and Social Psychology Bulletin, 37, 330-349.

Shu, L. L., Mazar, N., Gino, F., Ariely, D., \& Bazerman, M. H. (2012). Signing at the beginning makes ethics salient and decreases dishonest self-reports in comparison to signing at the end. Proceedings of the National Academy of Sciences, 109, 15197-15200.

Shweder, R. A., Mahapatra, M., \& Miller, J. G. (1990). Culture and moral development. In J. W. Stigler, R. A. Shweder \& G. Herdt (Eds.), Cultural psychology: Essays on comparative human development (pp. 130-204). New York, NY, US: Cambridge University Press.

Siegel, A. E., \& Kohn, L. G. (1959). Permissiveness, permission, and aggression: The effect of adult presence or absence on aggression in children's play. Child Development, 30, 131141.

Sims, R. R. (1992). Linking groupthink to unethical behavior in organizations. Journal of Business Ethics, 11, 651-662.

Smith, P. C. P., \& Walker, J. W. (2000). Layoff policies as a competitive edge. Competitiveness Review: An International Business Journal, 10, 132-145.

Smith, R. H., Parrott, W. G., Ozer, D., \& Moniz, A. (1994). Subjective injustice and inferiority as predictors of hostile and depressive feelings in envy. Personality and Social Psychology Bulletin, 20, 705-711.

Smyth, M. M., \& Fuller, R. G. (1972). Effects of group laughter on responses to humorous material. Psychological Reports, 30, 132-134.

Spranca, M., Minsk, E., \& Baron, J. (1991). Omission and commission in judgment and choice. Journal of Experimental Social Psychology, 27, 76-105.

Staw, B. M., \& Boettger, R. D. (1990). Task revision: A neglected form of work performance. Academy of Management Journal, 33, 534-559.

Stone, D. (1988). Policy paradox and political reason. New York: Harper Collins.

Suls, J., Martin, R., \& Wheeler, L. (2002). Social comparison: Why, with whom, and with what effect? Current Directions in Psychological Science, 11, 159-163.

Surette, R. (2002). Self-reported copycat crime among a population of serious and violent juvenile offenders. Crime \& Delinquency, 48, 46-69.

Surette, R. (2007). Media, crime, and criminal justice: Images, realities, and policies (4th ed.). Belmont, CA: Thomson/Wadsworth.

Sutherland, E. H. (1983). White collar crime: The uncut version (Rev. ed.). New Haven: Yale University Press. 
Swann, W. B. (1983). Self-verification: Bringing social reality into harmony with the self. Psychological perspectives on the self, 2, 33-66.

Swann, W. B. (1990). To be adored or to be known: The interplay of self-enhancement and selfverification. In R. M. Sorrentino \& E. T. Higginis (Eds.), Motivation and Cognition (Vol. 2, pp. 408-448). New York: Guilford Press.

Swann, W. B., Pelham, B. W., \& Krull, D. S. (1989). Agreeable fancy or disagreeable truth? Reconciling self-enhancement and self-verification. Journal of Personality and Social Psychology, 57, 782.

Swann, W. B., \& Read, S. J. (1981). Self-verification processes: How we sustain our selfconceptions. Journal of Experimental Social Psychology, 17, 351-372.

Tajfel, H. (1970). Experiments in intergroup discrimination. Scientific American, 223, 96-102.

Tajfel, H. (1982). Social psychology of intergroup relations. Annual Review of Psychology, 33, $1-40$.

Tajfel, H., \& Turner, J. C. (1979). An integrative theory of intergroup conflict. In W. G. Austin \& S. Worchel (Eds.), The social psychology of intergroup relations (pp. 33-47). Monterey, CA: Brooks/Cole.

Tangney, J. P., Stuewig, J., \& Mashek, D. J. (2007). Moral emotions and moral behavior. Annual Review of Psychology, 58, 345-372.

Tangney, J. P., Wagner, P. E., Hill-Barlow, D., Marschall, D. E., \& Gramzow, R. (1996). Relation of shame and guilt to constructive versus destructive responses to anger across the lifespan. Journal of Personality and Social Psychology, 70, 797-809.

Tarde, G. d. (1968). Penal philosophy (Vol. no. 16). Montclair, N.J.: Patterson Smith.

Tenbrunsel, A. E. (1998). Misrepresentation and expectations of misrepresentation in an ethical dilemma: The role of incentives and temptation. Academy of Management Journal, 41, 330-339.

Tenbrunsel, A. E., Diekmann, K. A., Wade-Benzoni, K. A., \& Bazerman, M. H. (2010). The ethical mirage: A temporal explanation as to why we are not as ethical as we think we are. Research in Organizational Behavior, 30, 153-173.

Tenbrunsel, A. E., \& Messick, D. M. (1999). Sanctioning systems, decision frames, and cooperation. Administrative Science Quarterly, 44, 684-707.

Tenbrunsel, A. E., \& Messick, D. M. (2004). Ethical fading: The role of self-deception in unethical behaviour. Social Justice Research, 17, 223-236.

Tenbrunsel, A. E., Smith-Crowe, K., \& Umphress, E. E. (2003). Building houses on rocks: The role of the ethical infrastructure in organizations. Social Justice Research, 16, 285-307.

Tesser, A., \& Collins, J. E. (1988). Emotion in social reflection and comparison situations: Intuitive, systematic, and exploratory approaches. Journal of Personality and Social Psychology, 55, 695-709.

The Economist. (2010, July 23). Dell's SEC settlement: Taking away Dell's cookie jar. Retrieved from http://www.economist.com/blogs/newsbook/2010/07/dells_sec_settlement.

Thrash, T. M., Elliot, A. J., Maruskin, L. A., \& Cassidy, S. E. (2010). Inspiration and the promotion of well-being: Tests of causality and mediation. Journal of Personality and Social Psychology, 98, 488-506.

Toffler, B. L. (2003). Final accounting: Ambition, greed, and the fall of Arthur Andersen. New York: Random House.

Treviño, L. K., \& Youngblood, S. A. (1990). Bad apples in bad barrels: A causal analysis of ethical decisionmaking behavior. Journal of Applied Psychology, 75, 378-385. 
Turner, J. C. (1999). Some current issues in research on social identity and self-categorization theories. In N. Ellemers, R. Spears \& B. Doosje (Eds.), Social identity: Context, commitment, content (pp. 6-34). Oxford: Blackwell.

Turner, J. C., Hogg, M. A., Oakes, P. J., Reicher, S. D., \& Wetherell, M. S. (Eds.). (1987). Rediscovering the social group: A self-categorization theory. New York: Basil Blackwell.

Turner, M. E., \& Pratkanis, A. R. (1998). A social identity maintenance model of Groupthink. Organizational Behavior and Human Decision Processes, 73, 210-235.

Tyler, T. R., \& Bies, R. J. (1990). Beyond formal procedures: The interpersonal context of procedural justice. In J. Carroll (Ed.), Applied social psychology and organizational settings (pp. 77-98). Hillsdale, NJ: Erlbaum.

Tyson, T. (1990). Believing that everyone else is less ethical: Implications for work behavior and ethics instruction. [Article]. Journal of Business Ethics, 9, 715-721.

Tyson, T. (1992). Does believing that everyone else is less ethical have an impact on work behavior? [Article]. Journal of Business Ethics, 11, 707-717.

Umphress, E. E., \& Bingham, J. B. (2011). When employees do bad things for good reasons: Examining unethical pro-organizational behaviors. Organization Science, 22, 621-640.

Umphress, E. E., Bingham, J. B., \& Mitchell, M. S. (2010). Unethical behavior in the name of the company: The moderating effect of organizational identification and positive reciprocity beliefs on unethical pro-organizational behavior. Journal of Applied Psychology, 95, 769-780.

Valdesolo, P., \& DeSteno, D. (2008). The duality of virtue: Deconstructing the moral hypocrite. Journal of Experimental Social Psychology, 44, 1334-1338.

Van Dyne, L., Graham, J. W., \& Dienesch, R. M. (1994). Organizational citizenship behavior: Construct redefinition, measurement, and validation. Academy of Management Journal, 37, 765-802.

Van Iddekinge, C. H., Roth, P. L., Raymark, P. H., \& Odle-Dusseau, H. N. (2012). The criterionrelated validity of integrity tests: An updated meta-analysis. [Article]. Journal of Applied Psychology, 97, 499-530.

Van Lange, P. A. M. (1991). Being better but not smarter than others: The Muhammad Ali effect at work in inerpersonal situations. Personality and Social Psychology Bulletin, 17, 689693.

Van Lange, P. A. M., \& Sedikides, C. (1998). Being more honest but not necessarily more intelligent than others: Generality and explanations for the Muhammad Ali effect. European Journal of Social Psychology, 28, 675-680.

Vaughan, D. (1998). Rational choice, situated action, and the social control of organizations. Law and Society Review, 32, 23-61.

Vecchio, R. (2005). Explorations in employee envy: Feeling envious and feeling envied. Cognition and Emotion, 19, 69-81.

Vecchio, R. P. (2000). Negative emotion in the workplace: Employee jealousy and envy. International Journal of Stress Management, 7, 161-179.

Vohs, K. D. (2006). Self-regulatory resources power the reflective system: Evidence from five domains. Journal of Consumer Psychology, 16, 217-223.

Vohs, K. D., \& Baumeister, R. F. (2007). Introduction to special issue: Emotion and decision making. Review of General Psychology, 11, 98-98.

Vohs, K. D., Baumeister, R. F., \& Loewenstein, G. (Eds.). (2007). Do emotions help or hurt decision making? A hedgefoxian perspective. New York: Russell Sage Foundation. 
Walumbwa, F. O., Mayer, D. M., Wang, P., Wang, H., Workman, K., \& Christensen, A. L. (2011). Linking ethical leadership to employee performance: The roles of leader-member exchange, self-efficacy, and organizational identification. Organizational Behavior and Human Decision Processes, 115, 204-213.

Warren, D. E., \& Smith-Crowe, K. (2008). Deciding what's right: The role of external sanctions and embarrassment in shaping moral judgments in the workplace. Research in Organizational Behavior, 28, 81-105.

Weber, J. M., Kopelman, S., \& Messick, D. M. (2004). A conceptual review of decision making in social dilemmas: Applying a logic of appropriateness. Personality and Social Psychology Review, 8, 281-307.

Weber, M. (1994). Sociological writings. New York: The Continuum Publishing Company.

Wenzel, M. (2005). Misperceptions of social norms about tax compliance: From theory to intervention. Journal of Economic Psychology, 26, 862-883.

White, J., Bandura, A., \& Bero, L. A. (2009). Moral disengagement in the corporate world. Accountability in Research, 16, 41-74.

Whyte, K. (2011, September 12). In conversation: Conrad Black, Macleans. Retrieved from http://www2.macleans.ca/tag/conrad-black/.

Wilson, T. D., \& Schooler, J. W. (1991). Thinking too much: Introspection can reduce the quality of preferences and decisions. Journal of Personality and Social Psychology, 60, 181-192.

Wintour, P., \& Syal, R. (2012, June 21). Jimmy Carr apologises for 'terrible error of judgment' over tax scheme, The Guardian. Retrieved from http://www.guardian.co.uk/culture/2012/jun/21/jimmy-carr-apologises-error-tax.

Wolfe, D. (1988). Is there integrity in the bottomline? Managing obstacles to executive Iintegrity. In S. Srivastva (Ed.), Executive integrity: The search for high human values in organization life (pp. 140-171). San Francisco: Jossey-Bass.

Yaeger, P. C. (1986). Analyzing corporate offenses: Progress and prospects. In J. Post (Ed.), Research in corporate social performance and policy (Vol. 8, pp. 93-120). Greenwich, CT: JAI Press.

Yin, T. (1992, June 12). Sears is accused of billing fraud at auto centers. Wall Street Journal, B1.

Yun, K. A. (2002). Similarity and attraction. In M. Allen, R. W. Preiss, B. M. Gayle \& N. Burrell (Eds.), Interpersonal communication research: Advances through meta-analysis (pp. 145-167). Mahwah, NJ: Lawrence Erlbaum.

Zellner, W. (2002, February 11). Jeff Skilling: Enron's missing man, Business Week. Retrieved from $\mathrm{http}$ ://www.businessweek.com/magazine/content/02_06/b3769051.htm.

Zhong, C.-B., Ku, G., Lount, R., \& Murnighan, J. (2010). Compensatory ethics. [Abstract]. Journal of Business Ethics, 92, 323-339.

Zibel, A., \& Aversa, J. (2010, April 19). Dick Fuld: Former Lehman CEO to claim 'no recollection' of accounting fraud, Huffington Post. Retrieved from http://www.huffingtonpost.com/2010/04/19/dick-fuld-former-lehman-c_n_543797.html.

Zimbardo, P. G. (1970). The human choice: Individuation, reason and order vs. deindividuation, impulse and chaos. In W. J. Arnold \& D. Levine (Eds.), 1969 Nebraska symposium on motivation (pp. 237-307). Lincoln, NB: University of Nebraska Press.

Zimbardo, P. G. (2007). The Lucifer effect: Understanding how good people turn evil. New York: Random House. 
Zimbardo, P. G., Haney, C., Banks, W. C., \& Jaffe, D. (1973, April 8). The mind is a formidable jailer: A Pirandellian prison, The New York Times Magazine. Retrieved from http://www.prisonexp.org/pdf/pirandellian.pdf. 